\title{
Kuwait: 2005 Article IV Consultation-Staff Report; Staff Statement; and Public Information Notice on the Executive Board Discussion
}

Under Article IV of the IMF's Articles of Agreement, the IMF holds bilateral discussions with members, usually every year. In the context of the 2005 Article IV consultation with Kuwait, the following documents have been released and are included in this package:

- $\quad$ the staff report for the 2005 Article IV consultation, prepared by a staff team of the IMF, following discussions that ended on December 12, 2005, with the officials of Kuwait on economic developments and policies. Based on information available at the time of these discussions, the staff report was completed on March 8, 2005. The views expressed in the staff report are those of the staff team and do not necessarily reflect the views of the Executive Board of the IMF.

- $\quad$ a staff statement of April 25, 2005 updating information on recent developments.

- $\quad$ a Public Information Notice (PIN) summarizing the views of the Executive Board as expressed during its April 25, 2005 discussion of the staff report that concluded the Article IV consultation.

The document listed below has been or will be separately released.

\section{Selected Issues Paper and Statistical Appendix}

The policy of publication of staff reports and other documents allows for the deletion of market-sensitive information.

To assist the IMF in evaluating the publication policy, reader comments are invited and may be sent by e-mail to publicationpolicy@imf.org.

\author{
Copies of this report are available to the public from \\ International Monetary Fund • Publication Services \\ $70019^{\text {th }}$ Street, N.W. • Washington, D.C. 20431 \\ Telephone: (202) 623-7430 • Telefax: (202) 623-7201 \\ E-mail: publications@imf.org • Internet: http://www.imf.org
}

Price: $\$ 15.00$ a copy

\section{International Monetary Fund Washington, D.C.}




\title{
INTERNATIONAL MONETARY FUND
}

\author{
KUWAIT
}

\section{Staff Report for 2005 Article IV Consultation}

\author{
Prepared by Staff Representatives for the 2005 Consultation with Kuwait
}

Approved by Saleh M. Nsouli and Juha Kähkönen

March 7, 2005

- $\quad$ The 2005 Article IV consultation discussions were held in Kuwait from November 29 to December 12, 2004.

- $\quad$ The team comprised Messrs. Mansur (head), Delgado, Davoodi, Govil, and Takizawa (all MCD). Mr. Shaalan, Executive Director for Kuwait, also participated in the policy discussions.

- $\quad$ The mission met with Mr. Abdullah Abdul Rahman Al-Taweel, Minister of Commerce and Industry; Sheikh Salem Abdulaziz Al-Sabah, Governor, Central Bank of Kuwait (CBK); Mr. Nabeel Al-Mannae, Deputy Governor, CBK; Dr. Yousef Al-Ebraheem, Economic Advisor to the Prime Minister; Mr. Abdul Muhsen Yousif Al-Hunaif, Under Secretary, Ministry of Finance; Ms. Sarah Ahmad Al-Duwaisan, Under Secretary, Ministry of Planning; and other government officials and private sector representatives.

- In concluding the 2003 Article IV consultation on February 9, 2004, Executive Directors commended the Kuwaiti authorities for pursuing cautious macroeconomic policies over the past several years, which had resulted in sizeable fiscal and external current account surpluses, a comfortable level of net foreign reserves, and low inflation. Directors considered that the main challenges ahead were to accelerate non-oil economic growth in order to absorb the rapidly growing Kuwaiti labor force and maintain intergenerational equity over the long run, as well as to reduce the budgetary dependence on oil revenue. They endorsed the official strategy of pursuing structural reforms and fiscal strengthening to achieve these objectives. In particular, they encouraged accelerating reforms to reduce state involvement in the economy, promote private investment, and improve the functioning of the labor market. While commending the authorities for the strong overall fiscal position, they noted that the non-oil fiscal deficit remained high, and supported the authorities' intention to implement fiscal policy in the context of a medium-term macroeconomic framework by adopting a three-year rolling budget.

- $\quad$ Kuwait accepted the obligations of Article VIII on April 5, 1963. It also accepted the Fourth Amendment of the Fund's Articles of Agreement.

- The authorities will consider issuing the Public Information Notice (PIN) and publishing the staff report following the conclusion of the Article IV consultation discussion by the Executive Board. 


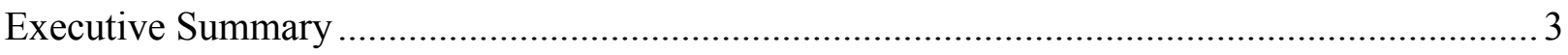

I. Background and Recent Developments .............................................................. 4

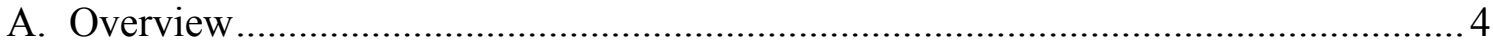

B. Recent Macroeconomic Developments and Structural Reforms, 2003-04 ............... 6

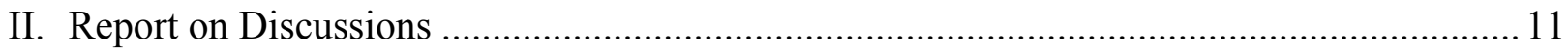

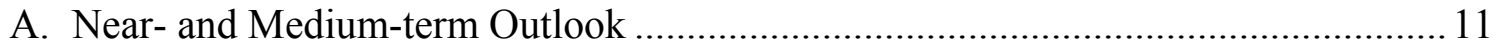

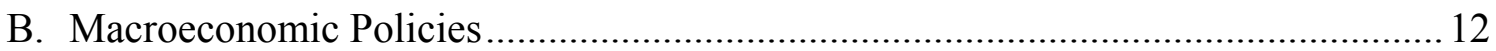

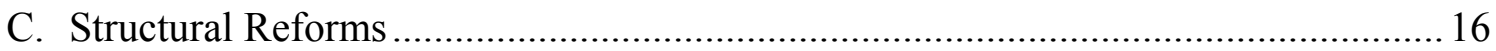

D. External Sector Policy and Regional Integration............................................. 17

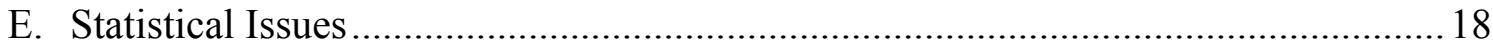

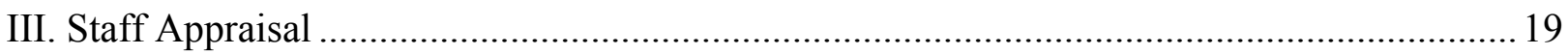

\section{Text Boxes}

1. Kuwait at an Important Crossroad: The Way Forward................................................... 5

2. Institutional Developments in the Financial Sector ................................................... 10

3. Is the Current Fiscal Stance Sustainable in the Long Run? ............................................. 14

\section{Text Tables}

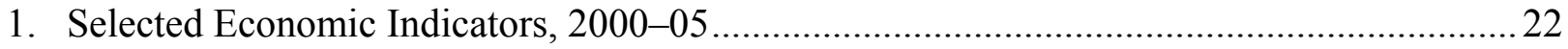

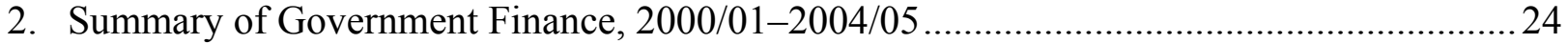

3. Summary of Balance of Payments, 2000-05 ................................................................ 25

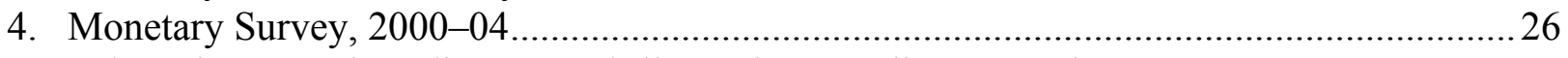

5. Selected Economic Indicators and Illustrative Baseline Scenario, 2000-09.....................2 27

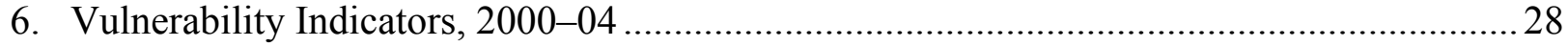

\section{Appendices}

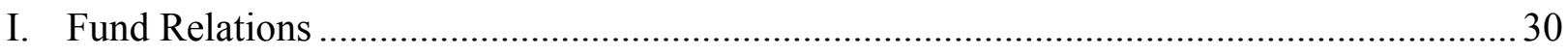

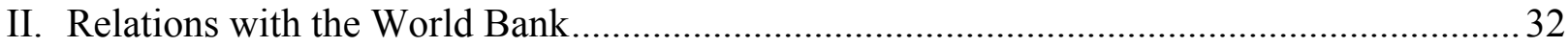

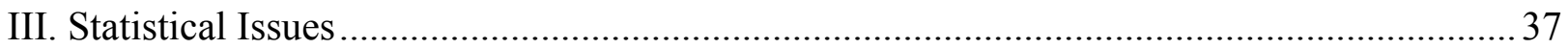




\section{EXECUTIVE SUMMARY}

\section{Current Setting}

Reflecting sharply higher oil prices and production, economic conditions improved significantly in 2003 and 2004. Real GDP grew at an average rate of 8.5 percent during the two-year period, its highest pace in the preceding decade and a half. The rebound was also supported by the spillover effects of the renewed trade relations with Iraq, which in part explained the increase in non-oil GDP growth to 5.5 percent in 2004. Inflation remained low. The Kuwaiti stock price index more than doubled in 2003, and increased further by 34 percent in 2004, reflecting improved general economic conditions and abundant liquidity.

Over the medium term, the economic and financial positions are projected to remain strong mainly on the expectation that world oil prices will decline only gradually. There are downside risks to this favorable medium-term outlook, since it is based on a historically high level of oil price and output assumptions. The main economic challenge facing Kuwait is to create sufficient employment opportunities for the rapidly growing national labor force by accelerating the growth of the private non-oil economy.

\section{Policy Discussions}

- Although the overall fiscal position is projected to remain in comfortable surplus over the medium term, the staff cautions the authorities about the sustainability of the rapid increase in budgetary spending and recommends a strengthening of the structure of the budget through containment of the wage bill and rationalization of transfers. Managing Kuwait's large and growing savings for future generations will also be key to long-term fiscal viability.

- $\quad$ Non-oil exports have surged in the aftermath of the Iraq war, but sustainability of the increase from their low base remains a challenge. The authorities are of the view that by positioning Kuwait as a regional trading hub, increasing investment in petrochemical projects and the continued GCC integration would help Kuwait to sustain higher non-oil output and exports.

- $\quad$ Monetary management has been prudent, and succeeded in maintaining price stability and the exchange rate peg. Since credit expansion continued at a pace much faster than the growth of the deposit base, recognizing the systemic risk to the financial system, the authorities imposed a ceiling on the ratio of bank loans to deposits at 80 percent in July 2004. The authorities underscored the need for firm actions, but also intend to abolish the ceiling once domestic credit expansion stabilizes. Significant progress has been achieved in strengthening the financial sector institutions and in implementing the FSAP recommendations.

- $\quad$ Progress has also been made on the structural reform front, albeit at a slow pace. Under the Kuwaitization policy, the authorities are pursuing a two-pronged strategy entailing imposition of sector-specific quotas and training of the unemployed Kuwaitis. The staff calls for limiting public sector hiring to essential areas, establishing links between public sector wages and productivity, and rationalizing public sector benefits.

- While progress has been made in the dissemination of financial and fiscal data, efforts would be needed to address data weaknesses in a number of areas. 


\section{BACKGROUND AND RECENT DEVELOPMENTS}

\section{A. Overview ${ }^{1}$}

1. The 2004 consultation discussion was held against the backdrop of accelerating economic activity, high oil prices, and large fiscal and external current account surpluses. Reflecting sharply higher oil prices and production, economic conditions improved significantly in 2003 and 2004. Strong growth in oil revenue generated substantial fiscal and current account surpluses, but further increased Kuwait's dependence on oil. ${ }^{2}$ The effects of the renewed trade relations with Iraq also supported economic growth. Kuwait continues to depend heavily on foreign workers comprising nearly two-thirds of its population of 2.6 million and four-fifths of its labor force of 1.6 million in June 2004. The immigrant labor force has increased further by about 30 percent during the period 2000 to end-June $2004 .^{3}$

\section{Since 2000, the Kuwaiti authorities have undertaken a comprehensive structural} reform program to: (a) accelerate non-oil GDP growth; (b) generate employment for the Kuwaiti nationals at a fast pace; and (c) ensure fiscal surpluses so as to maintain intergenerational equity over the long run. The staff and the authorities agree on the appropriateness of this strategy. In the previous Article IV consultations, the staff made recommendations and encouraged the authorities to speed up structural reforms, strengthen the budget structure, train Kuwaiti labor force, and apply sector specific quotas in a flexible manner. Progress has been made in many of these areas, although the implementation of the reform agenda has been slower than expected, in part, due to difficulties in reaching a political consensus and regional uncertainties. Financial sector institutional framework has been strengthened further, including implementation of some of the FSAP recommendations. Preparations are underway to implement the three-year rolling budget by 2006/07 in line with the FAD mission's recommendations; however, efficient ways of transferring oil wealth and strengthened public expenditure management will be key to long-term fiscal sustainability. The authorities however look forward to accelerating the pace of reforms, taking advantage of the opportunities created by the post Iraq war developments (Box 1).

\footnotetext{
${ }^{1}$ Kuwait's relations with the Fund and the World Bank are summarized in Appendices I and II, respectively. Data issues are covered in Appendix III.

${ }^{2}$ In 2003, oil accounted for 51.2 percent of total GDP, 84 percent of total exports, and 77.2 percent of total budgetary revenue.

3 The accompanying Selected Issues Paper discusses Kuwait's economic structure, past economic performance, and future prospects.
} 


\section{Box 1. Kuwait at an Important Cross Road: The Way Forward}

Kuwait's economic structure and performance suffered greatly during the 1990s owing to the regional security situation and the shift to a more public sector-oriented economic program. The change of the regime in Iraq and the opening up of markets in the region have contributed to the current growth spurt in Kuwait and created a window of opportunity for sustaining this momentum leading to a more diversified economic structure dominated by the private sector. This box describes Kuwait's past legacy and its new challenges.

The invasion of Kuwait in 1990 and the destruction that followed altered the course of Kuwait's developmental path leading to a less diversified economy compared with other GCC countries, a larger public sector, and a slowdown in economic growth. The invasion was a major shock to an otherwise stable economic system and inflicted large human, physical, and financial losses. The high budgetary spending associated with rehabilitation and International Comparisons of Kuwait's Productivity Growth, 1980-2002 1/ reconstruction as well as changes in the composition of government spending

\begin{tabular}{lccccc}
\hline & \multicolumn{5}{c}{ Average Annual Rates of Change } \\
\cline { 2 - 6 } & Real Output & $\begin{array}{c}\text { Output } \\
\text { Per Worker }\end{array}$ & & Per Worker Contribution of \\
\cline { 4 - 6 } & & & Capital & Education & TFP \\
\hline Kuwait & 0.9 & -2.4 & 0.5 & 0.4 & -3.3 \\
MENA (19) & 3.8 & 0.5 & 0.5 & 0.4 & -0.4 \\
Oil exporters & 3.3 & -0.1 & 0.5 & 0.5 & -1.0 \\
Non-oil exporters & 4.4 & 1.3 & 0.4 & 0.4 & 0.4 \\
GCC & 3.6 & 0.2 & 0.6 & 0.3 & -0.7 \\
Developing countries & & & & & \\
$\quad$ Excluding East Asia and MENA) (44) & 3.4 & 1.0 & 0.7 & 0.3 & -0.1 \\
East Asia (7) & 6.3 & 3.9 & 2.0 & 0.4 & 1.5 \\
Industrialized countries (21) & 2.6 & 1.6 & 0.6 & 0.3 & 0.7 \\
Latin America (22) & 2.4 & -0.4 & -0.2 & 0.3 & -0.5 \\
South Asia (4) & 4.9 & 2.7 & 1.3 & 0.3 & 1.0 \\
\hline
\end{tabular}

toward wages, benefits, and transfers created hard-to-reverse expenditure commitments and contributed to greater inflexibility in the fiscal structure. The end of Kuwait's traditional role as a regional trading hub and the loss of export markets to Iraq led to a secular decline in non-oil exports and re-exports. Reflecting these developments and the security risk, private investment also declined steadily throughout the period contributing to low levels of non-oil GDP growth in Kuwait. Against this background, apart from a brief rebound following the 1990 invasion, there has been a secular decline in various measures of productivity (labor and the total factor productivity (TFP)).

The authorities are aware that Kuwait needs to increase its investment rate significantly, while simultaneously boosting its factor productivity. Their policy response to overcome these problems and reduce the dependence on oil entails: (i) opening up the economy; (ii) improving the investment climate; (iii) reestablishing Kuwait as a regional trading hub through various large scale projects; (iv) developing its petrochemical industry to broaden the non-oil production base; (v) developing oil reserves in the North Fields with possible private sector participation; (vi) increasing investment in the oil sector to boost oil production and refinery capacity; and (vii) adopting a phased approach to implementation of structural reforms by taking stock of outdated laws and regulations with the intention of amending them to suit a more market-friendly business environment.

The authorities hope that these reforms, if implemented appropriately, will increase private investment, augment the relative size of Kuwait's private sector, boost non-oil GDP growth to absorb the growing labor force, increase productivity, and diversify the economy. 


\section{B. Recent Macroeconomic Developments and Structural Reforms, 2003-04}

3. Kuwait's macroeconomic performance has been strong in 2003 and 2004 reflecting sharply higher oil prices and production (Table 1). Real GDP grew at an average rate of 8.5 percent during the two-year period, its highest pace in the preceding decade and a half. The rebound was also supported by the spillover effects of the renewed trade relations with Iraq and an expansionary fiscal policy, which account for the steady increase in non-oil GDP growth to an estimated 5.5 percent in 2004. After taking into account the terms-of-trade gains, per capita income increased by 34.5 percent during the two-year period to $\$ 19,560$ in 2004. Inflation remained low at less than 2 percent $^{4}$ and the rate of unemployment remained stable at about 3.5 percent despite higher labor force growth. The Kuwaiti stock price index more than doubled in 2003, and increased further by 34 percent in 2004, reflecting higher corporate profits, an improved economic outlook and abundant liquidity.
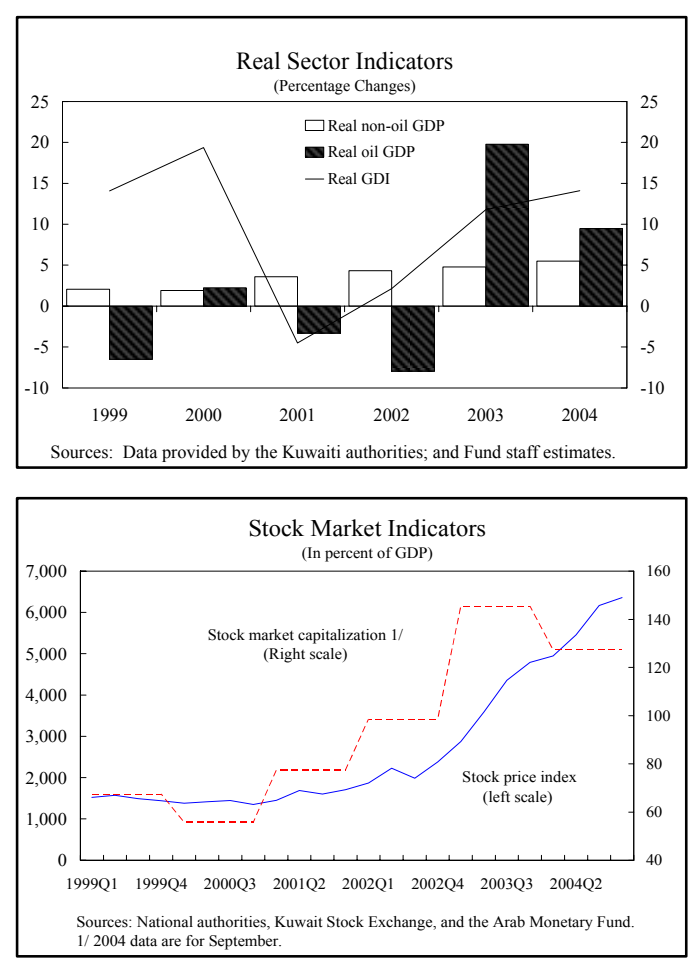

4. The central government budgetary position remained strong due to significantly higher oil revenues, with annual fiscal surpluses at about 20 percent of GDP (Table 2). Oil revenues increased by 33 percent during the twoyear period, while non-oil domestic revenues declined in nominal terms, mainly reflecting the declining Gulf war-related U.N. compensation payments. The stance of fiscal policy was expansionary in 2003/04 and 2004/05, as a large part of the higher oil revenue was spent on various government programs. ${ }^{5}$ In 2003/04, almost 90 percent of the increase in hydrocarbon revenues

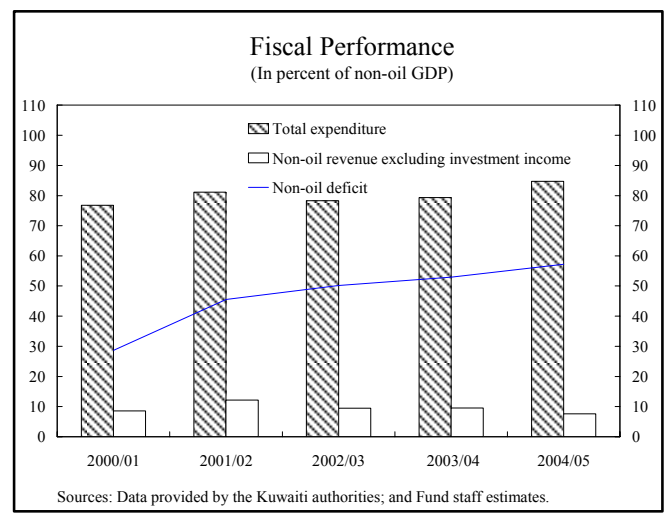

${ }^{4}$ The open and flexible nature of Kuwait's immigrant labor market, the policy of keeping the prices of public sector services, gasoline, water, and electricity unchanged, and the policy of not granting any general salary increase for the public sector employees have dampened to a large extent the inflationary effect of the KD depreciation in real effective terms.

5 Expenditure grew by 24 percent in real terms during 2003-04, but declined in relation to GDP because of the oil price induced sharp increase in nominal GDP. 
were spent on goods and services, subsidies and transfers, wages and salaries, and on capital projects. Although half of the increase in hydrocarbon revenues is expected to be saved in 2004/05, the growth in spending is projected to be higher than in the preceding year. A part of the increase in expenditure was attributable to security-related outlays and to a onetime transfer of higher oil revenues to the citizens. ${ }^{6}$ Wages and salaries, and subsidies and transfers also increased significantly and are estimated to have accounted for almost 70 percent of current expenditures. As a manifestation of the expansionary fiscal stance, the non-oil primary deficit as a percent of non-oil GDP increased by 8.3 percentage points during the two-year period to 59.3 percent in 2004. Most of the fiscal surplus was transferred to the Reserve Fund for the Future Generation (RFFG) and the General Reserve Fund (GRF), ensuring the most rapid asset buildup since the 1990 Gulf war.

\section{External sector}

5. With higher oil export receipts, the external current account surplus more than doubled in relation to GDP over the two-year period 2003-04 (Table 3). Exports grew at an annual rate of 33.6 percent due to a surge in oil and non-oil exports, the latter supported by a sharp increase in exports and re-exports to Iraq. Imports also increased sharply, driven by accelerating domestic activity and re-exports to Iraq. Although the services account deficit widened because of higher payments associated with travel and transportation, it was more than offset by higher investment income. As in the past, much of the current account surplus was invested abroad by both the public and private sectors, contributing to large capital account outflows. External reserves of the Central Bank of Kuwait (CBK) remained comfortable. ${ }^{7}$ The depreciation of the U.S. dollar against other major currencies and the low inflation in
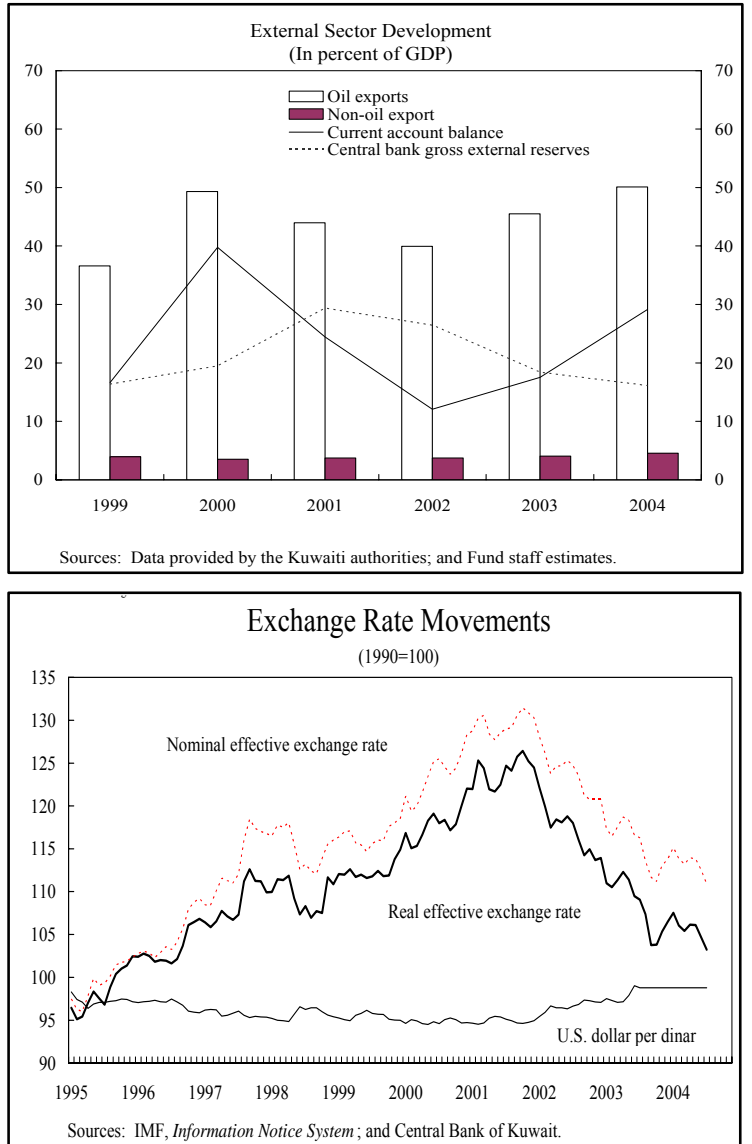

6 At the time of the Iraq war in 2003, security-related additional outlays amounted to KD 121 million (0.9 percent of GDP). The authorities also transferred KD 200 per citizen, amounting to KD 192 million (1.2 percent of GDP), in January 2005, in lieu of a general salary increase for the public sector employees.

7 The CBK foreign reserves declined by $\$ 1.7$ billion in 2003 reflecting the large expansion of credit by commercial banks, which was funded by the banks drawing down their excess (remunerated) reserves at the CBK. However, as monetary conditions tightened in the second-half of 2004, CBK external reserves increased by $\$ 0.7$ billion to about $\$ 8.4$ billion (5.7 months of imports) by end-December 2004 . 
Kuwait have contributed to a depreciation of the dinar by 9 percent in real effective terms during January 2003-October 2004. The continued depreciation of the dinar in real effective terms has largely corrected the appreciation experienced during 1995-2002, and has enhanced the competitiveness of non-oil exports.

\section{Monetary and financial developments}

6. Monetary policy has been consistent with the objective of maintaining the exchange rate peg, which also contributed to the continued price stability. In line with low U.S. interest rates, CBK's discount rate remained stable at 3.25 percent in 2003 and the interest rates on three-month $\mathrm{KD}$ deposits were stable at about 1.5 percent. The spread between the KD and the U.S. dollar deposit rates at domestic banks, which also remained stable in the range of $60-80$ basis points, was considered adequate to prevent potential capital outflows and to maintain the stability of the exchange rate. The record low interest rates, abundant liquidity, and increased trade with Iraq

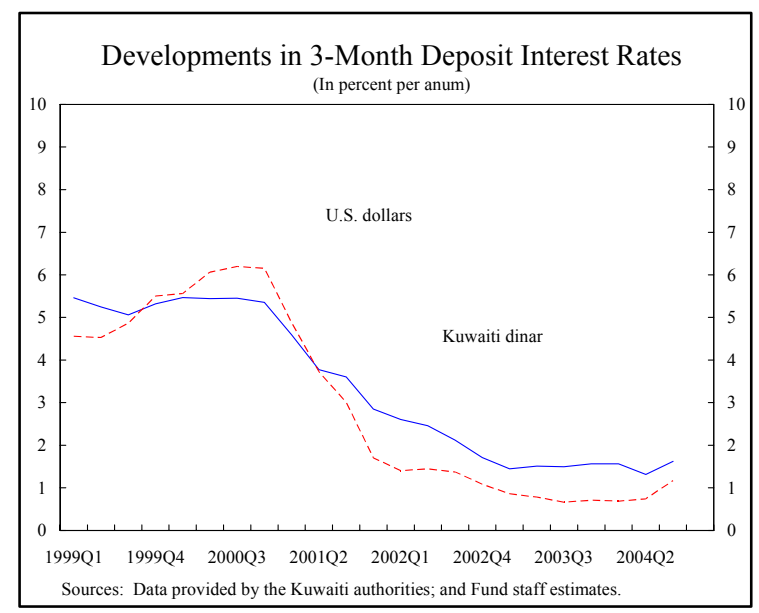
facilitated a 21 percent increase in credit to the private sector. The credit demand from the private sector was only partially offset by a decline in net credit to the government, resulting in an acceleration of broad money growth by 3 percentage points to 7.8 percent in 2003 .

7. Monetary conditions tightened in the second half of 2004, as a consequence of the increase in interest rates and the introduction of a ceiling on the credit to deposit ratio. In response to the rise in the U.S. Federal Funds rate and in order to widen the interest rate spread in favor of the $\mathrm{KD}$ to attract $\mathrm{KD}$ deposits, the CBK raised the discount rate on five occasions since July 2004, by 150 basis points to 4.75 percent by end-December 2004 . In July 2004, the authorities also imposed a ceiling on the ratio of credit (net of provisions) to deposits at 80 percent, in order to address a prudential concern regarding the rapid expansion of credit to the private sector over the last three years without a parallel increase in bank deposits. Banks have until June 2005 to comply fully with the ceiling. Since the average of the net credit to deposits ratio as of end-

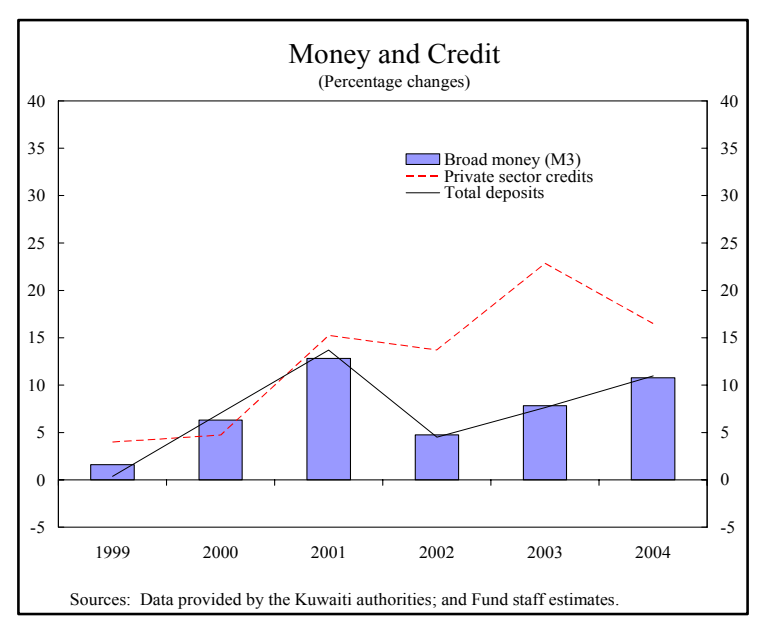
September 2004 was 78.6 percent, its introduction contributed to a gradual deceleration of the credit expansion to 15.3 percent over the 12-month period through end-December 2004 . 
8. The 2003 FSSA report concluded that Kuwaiti banks were well capitalized and liquid, with no imminent threat to the stability of the banking system. ${ }^{8}$ Despite the rapid expansion of credit, the capital adequacy ratio (CAR) remained comfortable at 17.3 percent as of end-September 2004, well above its minimum regulatory level of 12 percent. ${ }^{9}$ Asset quality also continued to improve and net bank profits and returns on equity also increased significantly. ${ }^{10}$ Progress was also made in strengthening the financial sector institutional framework, including in implementing some of the FSAP recommendations (Box 2).

\section{Structural reforms}

\section{Progress has been made on the structural reform front, albeit at a slow pace,} because of delays in reaching a political consensus. The Foreign Investment Law, which allows foreigners to own up to 100 percent of Kuwaiti companies, came into effect in $2003 .{ }^{11}$ A draft Privatization Law and an amendment to the Tax Law to lower the corporate income tax that applies only to foreign companies from 55 percent to 25 percent are awaiting parliamentary approval. The authorities allowed private sector participation in sectors previously dominated by the public sector and are also identifying the entities that could be privatized under the existing laws. The Kuwaitization ${ }^{12}$ policy has been in place since October 2003, entailing training of unskilled Kuwaiti nationals and enforcing quotas by imposing penalties. Under this policy, 3,000 Kuwaitis have been trained ${ }^{13}$ and, through the

\footnotetext{
${ }^{8}$ The Kuwaiti banking system with an asset base of KD19 billion (125 percent of GDP) accounts for about 75 percent of the assets of the financial system. Eleven banks are operating in Kuwait as of end-2004; out of which one is state-owned (with 2 percent market share), one is foreign-owned (about 1 percent market share), and two are Islamic banks (the second largest bank in Kuwait accounting for 6 percent of market share, and a new bank licensed in October 2004).

${ }^{9}$ The CAR declined by 2.4 percentage points between January 2003 and September 2004, primarily due to the expansion of credit.

10 The nonperforming loans ratio fell from 7.8 percent as of end-2002 to 5.4 percent by end-September 2004 . Net profits of banks increased by 21.2 percent in 2003 and a further 10 percent in the first three quarters of 2004 raising the return on equity to 20.4 percent as of end-September 2004.

11 The government has already approved projects amounting to $\$ 2.4$ billion under the law, and new investment proposals amounting to $\$ 1.8$ billion are under review by the Ministry of Commerce and Industry.

12 The Kuwaitization policy aims at increasing the proportion of Kuwaitis employed in the private sector by establishing targets (proportional to the workforce) that the nongovernment companies must observe. The proportion varies from sector to sector. Nongovernment companies not complying with the established limits are not allowed to conclude contracts or do business with the government.

${ }^{13}$ Twenty five percent of them have been hired by the private sector.
} 
enforcement of the new sector specific quotas, $8,000^{14}$ Kuwaitis have been hired by the private sector.

\section{Box 2. Institutional Developments in the Financial Sector}

The authorities have made commendable progress in strengthening the financial sector institutional framework. Substantial progress has been made in implementing most of the measures recommended by the 2003 FSSA report. The following are the salient institutional developments.

General: The blanket guarantee on bank deposits was removed in April 2004, and the CBK has started discussions with the banks in order to introduce a limited deposit insurance scheme.

Banking: (i) A legal amendment to Law 32/1968 on currency and banking was passed by parliament in January 2004 allowing the establishment of branches of foreign banks; a foreign bank (BNP Paribas) has been authorized to open a branch in Kuwait and other applications are being considered; (ii) the legal changes also enable CBK to exchange information with foreign supervisors, and CBK supervisory staff has conducted inspections of foreign subsidiaries of Kuwaiti banks; (iii) the minimum capital for local banks was increased from KD 3 million to KD 75 million, and a limit of 5 percent on a bank's capital ownership concentration was established, beyond which CBK's authorization is needed; and (iv) CBK's supervisory authority has been extended to Islamic banks, and the regulatory framework has been strengthened, in consultation with the Islamic Financial Services Board. As a result, Kuwait's financial regulation and supervision is currently compliant or largely compliant with all Basel Core Principles (BCP), according to the authorities' self-assessment.

Securities: A draft Capital Markets Law, creating a single, independent and accountable authority with full powers to develop and regulate the securities market and industry has been drafted. The law, which also addresses entry standards, insider trading, and market manipulation, is under review by the Ministry of Finance, prior to its eventual submission to parliament.

Insurance: A new Insurance Law has been drafted and submitted to the Ministry of Finance for review. The law will specify the independent nature of the insurance supervisory authority and define its institutional form. Training of about 20 insurance supervisors has already begun.

Payment system: The new Real Time Gross Settlement (RTGS) payment system is fully operational since August 2004; exposure limits were assigned to all participating institutions; and information on requirements to join the system is available from CBK upon request. Therefore, the authorities are confident that current regulations and practices comply with all the Core Principles for such systems.

AML/CFT: The National Committee for AML/CFT was reorganized in April 2004, in order to strengthen the AML/CFT strategy design and policy implementation. The amendments to the law 32/1968 on currency and banking enabled the sharing of information with other foreign AML/CFT authorities. In addition, the committee has prepared a draft executive order extending the coverage of AML/CFT oversight onto the broad financial sector, currently under review by the Ministry of Finance for its approval.

\footnotetext{
${ }^{14}$ This is equivalent to 0.6 percent of the total labor force in Kuwait and about 3 percent of the total Kuwaiti labor force in 2003. The total labor force in Kuwait was 1.45 million in 2003.
} 


\section{REPORT ON DISCUSSIONS}

10. The discussions focused on the recent economic developments and policy implementation; the outlook for 2005 and the medium term; the authorities' plans for accelerating the reform program; the need to improve the structure of the budget; the importance of strengthening further the financial sector; and developments with regard to the planned Gulf Cooperation Council (GCC) monetary union.

\section{A. Near- and Medium-Term Outlook}

11. In 2005, both the fiscal and external current account surpluses are projected to remain high. Real GDP, however, is projected to slow down to about 3 percent, since both oil and non-oil GDP growth are likely to taper off. The slowdown in non-oil GDP growth assumes that the pace of reform will remain sluggish, and as in the past, only a small part of private and public savings will be utilized domestically. The slowdown also reflects the wearing-off of the boost generated through the pickup in trade with Iraq. However, despite this slowdown in GDP growth, gross national income is expected to increase at a respectable pace boosted by higher investment income from abroad (10 percent of GDP).

\section{Over the medium term (2006-09), the economic and financial positions are}

projected to remain strong. Both the external current account and fiscal positions will remain in large surplus, albeit at declining levels, mainly reflecting the projected fall in oil prices (Table 5). In view of the expected slow pace of structural reforms, the concomitant absence of a broadening of the domestic non-oil production base, and as the spillover effects of the reconstruction of Iraq wear off, non-oil GDP growth is projected to gradually decline. The baseline outlook envisages a modest pickup in gross domestic investment, supported by higher private investment, but still insufficient to increase non-oil GDP to create jobs at a pace required for the fast growing Kuwaiti labor force. However, the outlook for investment income will improve significantly because of higher interest rates, contributing an additional 1.5-2 percent of GDP to the projected gross disposable income each year.

13. Kuwait's medium-term non-oil growth prospects depend critically on the pace of structural reforms to create the enabling conditions for attracting a much higher level of private investment in the domestic economy. Generating employment opportunities for the growing labor force will require much higher levels of domestic investment than observed in recent years. ${ }^{15}$ The authorities noted that the stepped-up efforts on their part to improve the investment climate and the strategy outlined in Box 1 should boost domestic

\footnotetext{
${ }^{15}$ The Kuwait labor force has been growing at about 6 percent per annum in recent year. Meanwhile, gross domestic investment as a percentage of GDP has declined sharply from pre-2000 levels (as percent of GDP to 8.7 percent of GDP in 2003), except for a modest pickup in 2004.
} 
investment, ${ }^{16}$ although the outlook is still uncertain. They also noted that further opening of the economy with the introduction of the GCC common external tariff and the initiatives under the Greater Arab Free Trade Area (GAFTA) should boost trade and growth prospects for the non-hydrocarbon sector.

\section{There are downside risks to the} favorable medium-term baseline outlook, since it is based on a historically high level of oil price and output assumptions. A large degree of uncertainty remains with regard to world oil demand and supply, pointing to substantial volatility and downside risks to the oil price projection, as experienced in the past. On the assumption of an oil price that is $\$ 5$ per barrel below the present WEO medium-term oil price projection-equivalent to about one standard deviation below the baseline - staff estimates indicate that the fiscal surplus in relation to

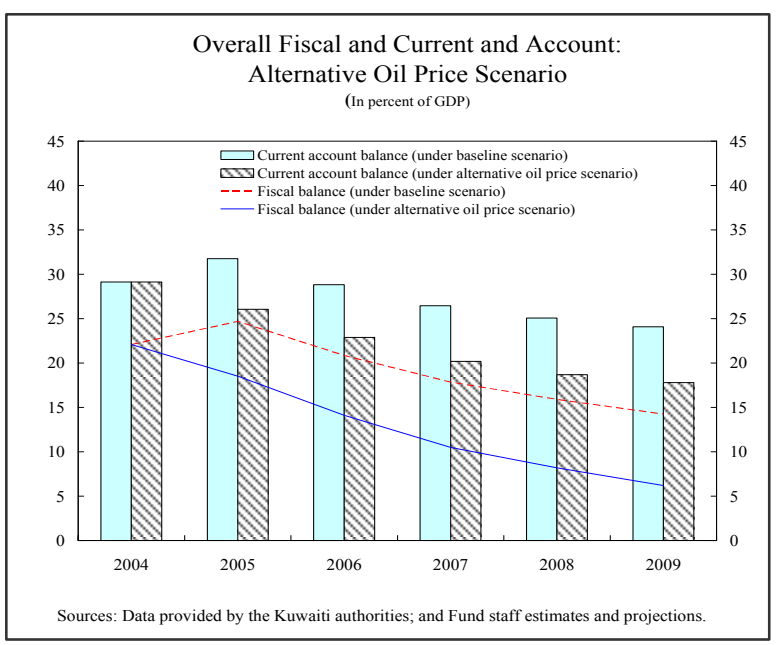
GDP would be 6 percentage points lower than in the baseline scenario in 2005/06, steadily declining to a surplus of only 6 percent of GDP by 2009/10. The current account surplus will also decline by 5-7 percentage points in relation to GDP over the medium term to reach 17.8 percent.

\section{B. Macroeconomic Policies}

\section{Fiscal policy}

15. Kuwait's fiscal strategy continues to be characterized by the distribution of a part of oil wealth to the current generation while building up sizable financial assets for future generations. The distribution of oil wealth to the current generation has been implemented through the creation of jobs in the public sector as well as through subsidies and transfers. Employment in the public sector accounted for more than 80 percent of Kuwaiti labor force in 2003, and wages, salaries, subsidies, and transfers are estimated to have amounted to 59 percent of government expenditure in 2003/04. Sizable assets for future generations have been built up by setting aside 10 percent of all government revenue for the Reserve Fund for Future Generations (RFFG) and saving the fiscal surpluses in the General Reserve Fund.

\footnotetext{
16 To this end, the construction of a port on Boubiyan Island (a joint public-private venture that is likely to be ready by 2008) and the proposed North-South GCC train line would contribute to higher investment and facilitate trade-related activities.
} 
16. Although the overall fiscal position is projected to remain in comfortable surplus over the medium term, the current high level of the non-oil deficit cannot be sustained over the long term. An unchanged fiscal stance will not only be inconsistent with the maintenance of total net wealth, the accumulated reserves could be exhausted within the next 25 years and lead to a buildup of debt at an unsuitable pace thereafter (Box 3$)^{17}$. Such high non-oil deficits may also create uncertainty and capacity problems in the non-oil economy. The staff accordingly recommended a strengthening of the structure of the budget through expenditure containment, rationalization of transfers, and revenue measures along the lines outlined in the baseline medium-term fiscal scenario. The fiscal stance underpinning the staff's medium-term scenario envisages a reduction in the non-oil primary deficit in relation to non-oil GDP over the medium term by 11 percentage points to historically normal levels. It also allows for a greater flexibility in making higher allocations for health, education, and infrastructure development, while at the same time permitting an accelerated accumulation of financial assets for future generations. The authorities acknowledged that achieving these objectives will require forceful measures limiting the growth of expenditure in the coming years, which would be possible politically once the surge in oil prices ends and the associated pressures for spending stabilize.

\section{The authorities should use efficient ways of transferring oil wealth and} strengthen public expenditure management. The staff underscored the need for not relying on the public sector as the "employer of last resort", and putting in place stricter controls on new hiring; and called for rationalizing subsidies and transfers, which accounted for more than 25 percent of total expenditure in 2003/04, and targeting them to the low-income families. The authorities noted that deliberations were continuing on the utility tariff rationalization issues, which could be concluded in the next two years. The staff supported the authorities' intention to use part of the higher oil revenue on education, health, and infrastructure projects, with due consideration given to absorptive capacity. The authorities should also implement the FAD technical assistance recommendations to improve public expenditure management and formulate fiscal policy in the context of a macroeconomic framework and a three-year rolling budget. The authorities observed that they were in the process of completing their discussions on the rolling budget with other ministries and hoped to have it in place by 2006/07. The staff urged the authorities to consider further harmonization of the tax structures (both direct and indirect) among the GCC countries and to introduce a value-added tax (VAT) at a low basic rate in coordination with other GCC countries.

\footnotetext{
${ }^{17}$ For more details on this issue, see the accompanying Selected Issues Paper.
} 


\section{Box 3. Is the Current Fiscal Stance Sustainable in the Long Run?}

Kuwait has accumulated large fiscal surpluses, enabling it to built up a sizeable asset position for the future generations. The fiscal position is also expected to remain comfortable over the medium term, but the recent rapid increase in expenditures raises doubts about the sustainability of the current fiscal stance over the longer term. Expenditures have grown at a very rapid pace in recent years, contributing to a sharp increase in the non-oil deficit (60 percent of non-oil GDP). This level is very high by international standards, and even by historical Kuwaiti standards. The issue of sustainability of the current fiscal stance is further compounded by the fact that more than 90 percent of government revenues are from oil and investment income from external financial assets, both of which are subject to significant global uncertainties.

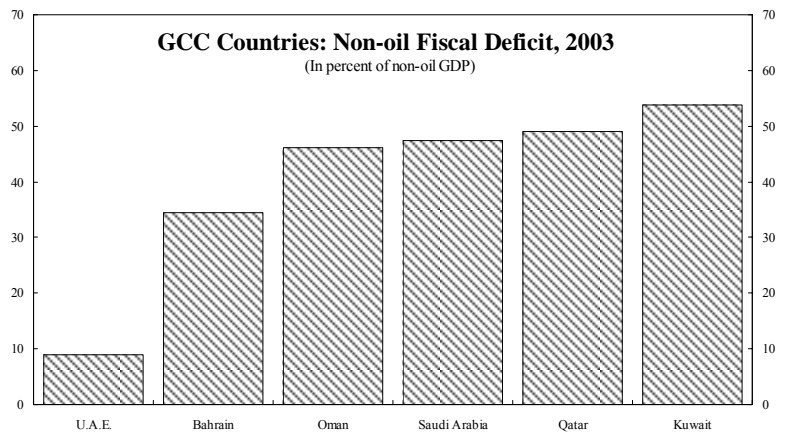

Source: Data provided by the national authorities; and Fund staff estimates.

The current fiscal stance is found to be unsustainable based on two different frameworks: the Permanent Income Hypothesis (PIH) of consumption and the standard debt sustainability analysis. The following analysis is based on "Fiscal Sustainability and Options for Adjustment" in the accompanying Selected Issues paper. Under both frameworks, the current fiscal policy stance is not sustainable with reasonable assumptions regarding global oil prices, Kuwait's real oil and non-oil sector growth rates, inflation rates, and nominal rates of return on financial assets. The PIH rule targets a constant total net wealth in real terms where total net wealth is defined as the sum of the value of hydrocarbon reserves and gross financial assets net of gross financial debt. The fiscal path for the period 2005-08 is assumed to be the medium-term fiscal scenario in Table 5. From 2009 onwards, however, the net primary deficit starts exceeding the

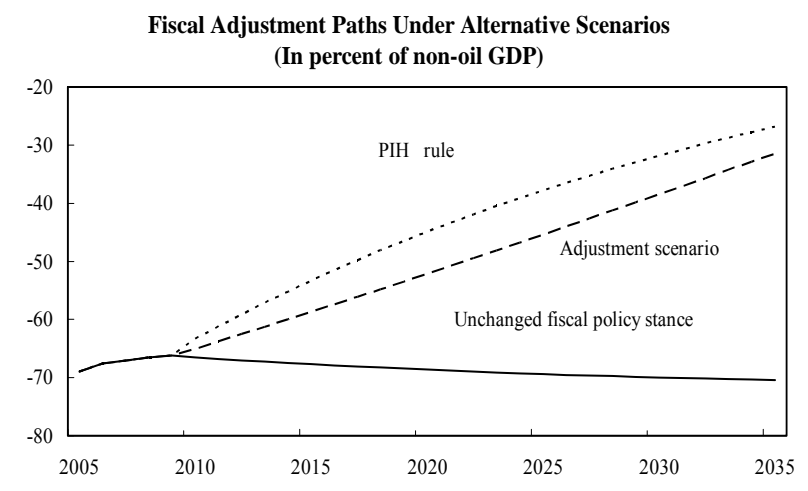
permissible level if expenditure in relation to non-oil GDP remains unchanged at the current level. The PIH approach, however, has its limitations since the path of fiscal stance that is implied is indeed a conservative one and is one of many that ensure fiscal sustainability. Also, such analysis is sensitive to changes in the key assumptions.

\section{A standard debt sustainability analysis also reconfirms that the unchanged fiscal policy stance would lead to exhaustion of accumulated assets and a rapid buildup of debt over the long term. For the first 20 years of the simulation, the net financial asset Net Financial Debt/Asset Under Alternative Scenario (In percent of GDP)} position is positive. However, the net financial asset position rapidly declines after 2012 and turns into a net debt position by 2030 as the increase in primary expenditure starts dominating the much smaller increase in revenues. Contributing to the smaller increase in revenues is a projected rather flat profile of oil export receipts. The unchanged fiscal policy cannot be maintained indefinitely (given the outlook for oil prices and production), no matter how large is Kuwait's net financial asset position; the growing fiscal deficit will eventually exhaust the financial

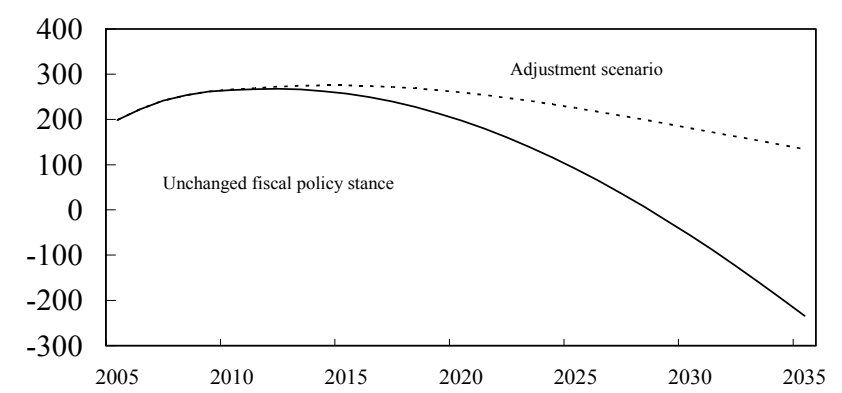
assets accumulated for the future generations, leading to unsustainable government debt levels. A possible fiscal adjustment scenario prepared by the staff points to $1 \frac{1}{2}$ percentage points of non-oil GDP in discretionary measures each year over the long term, to ensure a stable debt to GDP ratio. 
18. Proper safeguard arrangements and efficient management of RFFG assets will be key to Kuwait's long-term fiscal viability. Kuwait has built up a sizable investment abroad, despite the setback of the 1990 Gulf war, and the assets are likely to be built up at a faster pace in the coming years because of higher oil revenue. Investment income of the RFFG is already significant and is likely to assume greater importance over time. The authorities have ensured that safeguard arrangements were in place through internal and external audits of the investment accounts, in addition to oversights by the Board of Directors of the Kuwait Investment Authority and by parliament. The authorities concurred with the staff's observation that an efficient management of these assets would be key to Kuwait's long-term fiscal sustainability.

\section{Monetary and financial sector policies, and the exchange system}

\section{Monetary policy has been successful in maintaining price stability and} supporting the exchange rate peg. The Kuwaiti dinar has been officially pegged to the U.S. dollar since January 2003, and the authorities did not foresee a change in the exchange rate policy in the period leading up to the establishment of the GCC monetary union by 2010 . At this point, all options remain open regarding the exchange rate regime under the monetary union. The staff considers the peg sustainable. The recent real effective exchange rate depreciation and the surge in non-oil exports indicate that Kuwait's exchange rate remains competitive.

\section{The limit on the loans to deposit ratio was introduced because of prudential} considerations, and is expected to be abolished once domestic credit expansion stabilizes at a sustainable pace. The authorities explained that the implementation of the ratio responded to the need to preserve systemic stability, given the growth in loans to deposits ratio during the past three years. They were of the view that the ratios for many local banks reached uncomfortable levels, posing a systemic threat in the event of an adverse shock of domestic or external origin. The staff noted the effectiveness of the measure in containing the impact of a potential asset price correction on the stability of the financial system and endorsed the precedence of prudential concerns over other short-term effects that the measure may have. The staff, however, pointed out that this type of ceiling may have negative implications over the medium term, particularly on financial sector profitability and resource allocation. Accordingly, once domestic credit expansion stabilizes, the staff recommended addressing the prudential problem through strengthening of risk-based prudential ratios. The authorities explained that the stability of the financial system and the soundness of its units far outweighed the short-term profitability considerations, and the limit, together with other supervisory regulations, could provide an incentive for banks to maintain higher quality assets with sustainable returns. However, the authorities concurred with the staff's recommendation that the ceiling should be abolished once the required ratio is achieved by the local banks and domestic credit expansion stabilizes.

21. The staff welcomed the substantial progress achieved in strengthening the financial sector regulation and supervision, and in liberalizing the financial system, described in Box 2. The staff, however, expressed its concern about the possibility that the 
prevailing sector specific lending rate ceilings could be binding and that the ceilings, together with the ceiling on the credit to deposit ratio, may interfere with the efficient allocation of resources by the market. The authorities concurred with the staff's view, but noted that the sector specific ceilings were mandated by a law and, despite the recent increases in rates, the ceilings were not binding for the corporate lending rates. The staff underscored the importance of the two important draft laws aimed at providing the legal basis for the independence of the Capital Markets Authority and Insurance Supervision Authority, and hoped for their speedy legislation by parliament.

\section{Structural Reform}

\section{The authorities are pursuing a multi-pronged strategy to accelerate the} implementation of structural reforms. The government is articulating its reform strategy through various public awareness programs, particularly after the Prime Minister's recent trip to Asia. It has also taken several measures to open up the economy further. ${ }^{18}$

\section{The staff recommended that the authorities encourage market-based pricing of publicly provided goods and services, and foster FDI inflows into Kuwait. In particular,} appropriate pricing of electricity, petroleum products, and water should be part of the government action plan to encourage the growth of the private sector, ensure an efficient allocation of resources, and reduce the burden on the budget. ${ }^{19}$ In this context, the staff noted the importance of establishing a regulatory framework and appropriate institutional arrangements to ensure protection against monopolies; supported the authorities' efforts to foster FDI in Kuwait; encouraged them to improve the investment climate for boosting private investment in general and, for tax purposes, treat both domestic and foreign companies equally. The current FDI law stipulates a high degree of discretion for approving individual investment projects and a lengthy approval process for screening applicants. It does not have a clear "negative list" which is the best practice followed worldwide. ${ }^{20}$ The Foreign Investment Bureau, the investment agency created under the law to facilitate foreign investment, should also be independent and fully operational.

\footnotetext{
18 These include: (a) granting of visas to citizens of some 34 countries upon arrival in Kuwait; (b) issuing work permits to tourists who can find a willing employer within the first month of their arrival; and (c) taking stock of all outdated laws and regulations with the intention of amending them to suit a more market-friendly business environment.

${ }^{19}$ However, targeted subsidies could be considered to protect low-income families from the increase in the cost of living.

${ }^{20}$ Under the FDI by-laws, eleven sectors have been identified for 100 percent foreign ownership except for enterprises related to oil or gas explorations or production and others that are at the discretion of other government agencies.
} 
24. The authorities are responding to the higher global demand for oil with investment plans to boost capacity in the medium term. ${ }^{21}$ They are contemplating plans to rehabilitate existing oil refineries, add a new refinery, and increase oil production capacity to 4 million barrels per day by 2020. As regards development of Kuwait's oil reserves in the North Fields, which is expected to add some 480,000 barrels per day to Kuwait's production capacity, a draft law will be submitted to parliament and its approval is expected in 2005 . The staff encouraged the authorities to ensure the timeliness and transparency of data related to petroleum reserves, production, exports, and inventories, including in the context of the Joint Oil Data Initiative.

\section{The staff called for a cautious application of Kuwaitization policy and for an} intensification of efforts to raise the skills of the Kuwaiti labor force. The authorities are pursuing a two-pronged strategy entailing imposition of sector specific quotas and training of the unemployed Kuwaitis under the Manpower and Government Restructuring Program. The current policy of guaranteed employment in the public sector in order to alleviate the unemployment pressure raises the reservation wage for private sector jobs and acts as a disincentive for acquiring the skills needed for private sector jobs. The staff, therefore, called for limiting public sector hiring to essential areas, establishing links between public sector wages and productivity, rationalizing public sector benefits, and continuing the application of sector specific quotas in a flexible manner.

\section{External Sector Policy and Regional Integration}

\section{Although Kuwait's external balance of payments outlook remains comfortable} over the medium-term, it depends heavily on oil exports and the non-oil export base is very narrow. Despite the surge in non-oil exports in the aftermath of Iraq war, sustainability of the increase remains a challenge. Much of the increase has been due to petrochemical products and re-exports to Iraq. Domestic non-oil exports remain relatively small at about 3 percent of GDP. Furthermore, Kuwait's success in increasing exports of petrochemical products has been rather limited compared to other GCC countries. The authorities are of the view that the potential for further export growth is strong because of new investments in the petrochemical sector and Kuwait's efforts in establishing itself as a regional trading link. ${ }^{22}$ Regional trade and economic integration are also key elements of their strategy.

27. Progress continues in regional integration efforts. The GCC common external tariff at 5 percent rate is in effect since early 2003. Negotiations are ongoing among the GCC

\footnotetext{
${ }^{21}$ Production of crude oil has been increased to 2.5 million barrels per day in recent months, and through higher investments, capacity is expected to increase to 2.6 million barrels per day in 2005 and steadily to 3 million barrels per day by 2009 .

${ }^{22}$ The coming on stream of Equate II project, and the aromatics and styrene plants by 2008 will significantly increase Kuwait's export capacity.
} 
countries to prepare a common list of items to be prohibited for security and religious reasons. In connection with the envisaged monetary union among the members of the GCC, deliberations are continuing on: (a) identifying issues that would need to be addressed in establishing a common central bank; (b) establishing a common data standard and a common fiscal accounting framework to facilitate the adoption of macroeconomic convergence criteria by 2005; and (c) identifying other areas that would need further harmonization. Tariff cuts under the GAFTA initiative were continuing at an accelerated pace: in 2004, tariff rates were cut further by 20 percent; and all import duties were eliminated in January 2005.

\section{The staff commended the authorities for its generous external development} assistance program. In 2002/03, the Kuwait Fund for Arab Economic Development (KFAED) made loan commitments of KD 126.3 million (1.1 percent of GDP) to finance 15 projects in 14 countries. The authorities also agreed in principle to cut Iraqi debt owed to Kuwait (estimated at $\$ 8.2$ billion, excluding the U.N. war compensation) by 80 percent, in line with the terms offered by the Paris Club creditors; and has committed to provide $\$ 500$ million to Iraq in 2004 to finance infrastructure projects and an additional $\$ 60$ million for health and education projects. Kuwait has committed to provide $\$ 100$ million to the victims of the recent tsunami in Asia. ${ }^{23}$ It has also disbursed the full amount of its commitment to the HIPC Trust Fund (SDR 4.3 million).

\section{E. Statistical Issues}

\section{The staff reviewed the progress made in addressing data weaknesses and} recommended stepped-up efforts in a number of areas. Kuwait's data are adequate for the surveillance purpose. Monetary and financial data and fiscal data in non-GFS format are updated regularly and widely disseminated, by posting in websites. However, reporting on national income and customs data, the consumer price index, and the wholesale price index suffers from unusual delays. CBK relies on its own estimates of foreign trade data to publish balance of payments statistics on a timely basis, given the delays in preparing trade data by the customs department. The authorities observed that preparations were underway to expedite collection and computerization of customs data needed for the compilation of both national accounts and balance of payments statistics, and the problem should be resolved in the coming months. The staff called for improving the coverage of fiscal data relating to investment income, transfer of profits of public institutions, and interest payments on treasury bills and bonds. Looking forward, in collaboration with other GCC countries, the authorities also need to adopt common data standards across all sectors to ensure compliance with convergence criteria for the planned monetary union.

\footnotetext{
${ }^{23}$ Kuwait has also announced a freeze on the repayment of about $\$ 763$ million of loans extended to the six Asian countries affected by the tsunami.
} 


\section{STAFF APPRAisAL}

30. Kuwait has recorded a strong economic rebound and strengthened further its macroeconomic position due to higher oil output and prices. The highest pace of economic expansion since the 1990 Gulf-war, combined with the oil-related terms-of-trade gains, boosted per capita income and helped build up assets for future generations at a record pace. The removal of security threat from the former regime in Iraq, resumption of trade relations with Iraq, and the spillover effects of developments in Iraq combined with the boost from the surging oil exports receipts have created much optimism on the economic front. Large external current account and fiscal surpluses, a rapid pace of public sector asset buildup, and continued price stability have laid the foundation for potential vibrant private sector-led non-oil activities, as manifested by a booming stock market. These remarkable gains notwithstanding, generating employment opportunities for the fast growing Kuwaiti labor force in the domestic private sector remains a major challenge and will require faster non-oil growth led by the private sector over the medium term.

31. Accelerating the pace of structural reforms to further open up the economy for private sector investment will be critical to overcome the medium-term challenge. The authorities' intention to take advantage of the improved security situation and the opportunities created by reopened economic relations with Iraq and to reposition Kuwait in its traditional role as a gateway to regions to its north and east is appropriate. The associated infrastructure investment projects should be led and managed by the private sector, the public sector playing only the role of a facilitator to signal the shift in economic policy. An expeditious passage of the Privatization Law and a simultaneous broadening of private sector participation in primarily public sector dominated activities will be critical in this regard.

\section{Although Kuwait's fiscal position is projected to remain comfortable over the} medium term with continued sizeable surpluses, the sharp increase in the non-oil deficit in recent years is a source of concern. The pace of expenditure growth experienced in recent years is not sustainable, and by increasing the relative size of the public sector and raising the wage bill, this rapid growth in outlays is undermining the authorities' stated objective to increase the role of the private sector in the economy. A strengthening of the structure of the budget through expenditure containment and rationalization of transfers to reduce significantly the non-oil deficit should be the cornerstone of the authorities' mediumand longer-term fiscal strategy. To reduce the non-oil primary deficit in relation to non-oil GDP to historically normal levels over the medium term, and thereafter, move to a long-term adjustment path, would require a better targeting of subsidies, putting in place strict controls on new hiring, and not using the public sector as the "employer of last resort." Efficient management of Kuwait's large and fast-growing savings funds and protecting the investments will also be increasingly important for Kuwait's long-term fiscal sustainability.

33. Prudent conduct of monetary policy has supported the exchange rate peg and contributed to a remarkable degree of price stability. The strong non-oil export growth and the recent significant depreciation of the dinar in real effective terms also indicate that competitiveness is not a problem. The staff supports the authorities' intention to keep the 
exchange rate peg unchanged until the GCC monetary union and to remain open toward the choice of the exchange rate regime under the planned monetary union. The continued rapid expansion of credit for the last three successive years and the strong surge in stock prices, although partly backed by strong economic fundamentals, have posed some risks to the financial system. The authorities are rightly concerned about the systemic impact of domestic or external shocks on the stability of the financial system and had to implement some steps to stem the unsustainable pace of credit expansion. The limit on the loans to deposit ratio should help achieve this objective by containing credit expansion in line with the expansion of the banks' deposit base. Maintaining such an administrative ceiling, however, constrains market-based operations. Accordingly, the staff welcomes the authorities' intention to abolish the ceiling once domestic credit expansion stabilizes and recommends addressing the potential risks to the financial system through strengthening of risk-based prudential ratios.

\section{The Kuwaiti banking system is financially sound, well managed, and effectively}

supervised. The staff commends the authorities for the substantial progress achieved in the further liberalization of the financial system, and in strengthening the prudential regulations and supervision, including in implementing some of the FSAP recommendations. While taking note of these significant steps, the staff hopes that the legal basis for the independence of the capital market authority, the insurance supervision authority, and CBK's supervisory authority will be secured soon.

\section{Generating employment for the fast growing Kuwaiti labor force is the most} important economic challenge for Kuwait. Accelerating the pace of structural reform and reducing the relative size of the public sector operations to support private sector-led non-oil economic expansion in the midst of the oil revenue induced boom will not be easy politically. The reform initiative undertaken following the Prime Minister's East Asia trip is encouraging and should lead to a stronger push for legislative reforms and broader private sector role in sectors previously dominated by the government. Addressing the pressures for job creation through training and providing incentives for development of skills needed by the private sector is appropriate. However, despite the effectiveness of the sector specific quotas to force the private sector to hire Kuwaiti workers under the Kuwaitization policy, the policy should be applied flexibly so that the competitiveness and profitability of the private sector is not adversely affected. The staff underscores the promotion of market-based flexibility in wages for the Kuwaiti workforce in order to facilitate the integration of the segmented labor markets.

\section{Although progress has been made in compilation and dissemination of Kuwait's economic statistics, the staff recommends stepped-up efforts in a number of areas.} Although Kuwait's data are adequate for surveillance purpose, delays in collection and computerization of customs data have been a problem for regular and accurate compilation of national accounts and balance of payments statistics. The staff hopes that efforts underway to expedite collection and compilation of customs data will help resolve the problem. Steps will also be needed in coordination with other GCC countries to adopt common data standards across all sectors as a step toward establishing convergence criteria for the planned monetary 
union. Fund technical assistance, perhaps on a GCC-wide basis, would be particularly beneficial.

37. It is recommended that the next Article IV consultation take place on the standard 12-month cycle. 
Table 1. Kuwait: Selected Economic Indicators, 2000-05

\begin{tabular}{|c|c|c|c|c|c|c|}
\hline & 2000 & 2001 & 2002 & 2003 & $\frac{\text { Est. }}{2004}$ & $\frac{\text { Proj. }}{2005}$ \\
\hline \multicolumn{7}{|l|}{ Oil and gas sector } \\
\hline Total oil and gas exports (in billions of U.S. dollars) & 18.2 & 15.0 & 14.1 & 19.0 & 26.0 & 28.4 \\
\hline Average oil export price (in U.S. dollar/barrel) & 25.0 & 21.2 & 22.9 & 25.5 & 31.8 & 34.5 \\
\hline Crude oil production (in millions of barrels/day) & 1.98 & 1.95 & 1.75 & 2.11 & 2.30 & 2.32 \\
\hline Share of oil GDP in total GDP (in percent) & 53.4 & 47.5 & 45.2 & 51.2 & 55.7 & 56.4 \\
\hline & \multicolumn{6}{|c|}{ (Annual percentage change, unless otherwise indicated) } \\
\hline \multicolumn{7}{|l|}{ National accounts and prices } \\
\hline Nominal GDP (market prices, in billions of Kuwaiti dinar) & 11.3 & 10.4 & 10.7 & 12.4 & 15.3 & 16.5 \\
\hline Nominal GDP (market prices, in billions of U.S. dollars) & 36.9 & 34.1 & 35.2 & 41.7 & 51.8 & 56.1 \\
\hline Real GDP & 1.9 & 0.7 & -0.5 & 9.7 & 7.2 & 3.2 \\
\hline Real oil GDP & 2.2 & -3.3 & -7.9 & 19.8 & 9.5 & 0.7 \\
\hline Real non-oil GDP & 1.9 & 3.6 & 4.3 & 4.8 & 5.5 & 4.7 \\
\hline Real Gross Disposable Income (GDI) & 19.4 & -4.5 & 2.1 & 11.8 & 14.1 & 6.0 \\
\hline CPI inflation (average) & 1.6 & 1.4 & 0.8 & 1.0 & 1.8 & 1.8 \\
\hline Unemployment rate (Kuwaiti nationals) & 1.0 & 2.5 & 3.6 & 3.4 & $\ldots$ & $\ldots$ \\
\hline & \multicolumn{6}{|c|}{ (In percent of GDP at market prices) } \\
\hline \multicolumn{7}{|l|}{ Investment and savings } \\
\hline Investment & 7.7 & 8.7 & 9.2 & 8.7 & 11.2 & 12.3 \\
\hline Public & 1.8 & 2.2 & 3.0 & 2.8 & 4.5 & 4.4 \\
\hline Private & 5.9 & 6.6 & 6.2 & 5.8 & 6.7 & 7.9 \\
\hline Gross national savings & 47.1 & 33.2 & 21.2 & 26.8 & 40.4 & 44.1 \\
\hline Public & 43.2 & 24.1 & 27.5 & 26.6 & 29.0 & 29.6 \\
\hline Private & 3.9 & 9.1 & -6.3 & 0.2 & 11.3 & 14.5 \\
\hline Savings/investment balance $1 /$ & 39.4 & 24.4 & 12.1 & 18.1 & 29.1 & 31.8 \\
\hline & \multicolumn{6}{|c|}{ (In percent of GDP at market prices) } \\
\hline \multicolumn{7}{|l|}{ Budgetary operations 2/ } \\
\hline Revenue & 80.2 & 63.1 & 65.2 & 60.6 & 61.9 & 62.5 \\
\hline Oil & 55.5 & 43.1 & 49.4 & 46.8 & 49.0 & 48.8 \\
\hline Non-oil, of which & 24.7 & 20.0 & 15.8 & 13.8 & 12.9 & 13.7 \\
\hline Investment income & 20.3 & 13.2 & 10.5 & 8.8 & 9.4 & 10.1 \\
\hline Expenditures and net lending & 39.4 & 45.6 & 43.9 & 41.5 & 39.8 & 37.8 \\
\hline Of which: current & 36.2 & 40.8 & 38.8 & 36.3 & 34.4 & 33.0 \\
\hline capital & 3.2 & 4.0 & 4.7 & 4.8 & 4.5 & 4.5 \\
\hline Balance & 40.8 & 17.5 & 21.3 & 19.1 & 22.1 & 24.7 \\
\hline Domestic financing & -2.8 & -1.3 & -3.2 & -0.9 & -5.2 & -2.6 \\
\hline External financing & 0.0 & 0.0 & 0.0 & 0.0 & 0.0 & 0.0 \\
\hline Non-oil primary balance (in percent of non-oil GDP) & -25.0 & -44.6 & -51.0 & -56.9 & -59.3 & -52.8 \\
\hline Total gross debt (calendar year-end) & 35.0 & 36.0 & 32.5 & 26.4 & 19.5 & 17.1 \\
\hline & \multicolumn{6}{|c|}{ (Changes in percent of beginning broad money stock) } \\
\hline \multicolumn{7}{|l|}{ Money and credit } \\
\hline Net foreign assets & 11.5 & 6.5 & -4.1 & -4.8 & 10.9 & 2.3 \\
\hline Net domestic assets & -5.1 & 6.3 & 8.8 & 12.6 & -0.1 & 2.1 \\
\hline Claims on government (net) & -7.3 & -4.1 & 0.2 & -2.8 & -7.8 & -3.8 \\
\hline Claims on nongovernment sector & 3.9 & 11.1 & 10.5 & 17.2 & 13.8 & 6.4 \\
\hline
\end{tabular}


Table 1. Kuwait: Selected Economic Indicators, 2000-05

\begin{tabular}{|c|c|c|c|c|c|c|}
\hline & 2000 & 2001 & 2002 & 2003 & $\frac{\text { Est. }}{2004}$ & $\frac{\text { Proj. }}{2005}$ \\
\hline Broad money & 6.3 & 12.8 & 4.8 & 7.8 & 10.8 & 4.4 \\
\hline Velocity of broad money & 1.4 & 1.1 & 1.1 & 1.2 & 1.3 & 1.4 \\
\hline Kuwaiti dinar 3-month deposit rate (average in percent) & 5.4 & 3.7 & 2.2 & 1.5 & 2.0 & $\ldots$ \\
\hline U.S. dollar 3-month deposit rate (average in percent) & 6.0 & 3.3 & 1.3 & 0.7 & 1.3 & $\cdots$ \\
\hline Stock market index (annual percent change) & -6.5 & 26.8 & 39.0 & 101.7 & 33.8 & $\ldots$ \\
\hline & \multicolumn{6}{|c|}{ (In millions of U.S. dollars, unless otherwise indicated) } \\
\hline \multicolumn{7}{|l|}{ External sector } \\
\hline Exports of goods and services & 21,298 & 17,910 & 17,012 & 22,611 & 30,352 & 33,017 \\
\hline Of which: Oil and refined products & 18,182 & 14,977 & 14,057 & 19,004 & 25,951 & 28,385 \\
\hline Annual percentage change in volume & 9.0 & -0.3 & -12.1 & 20.0 & 8.2 & 0.0 \\
\hline Imports of goods and services & $-11,369$ & $-12,406$ & $-13,959$ & $-16,239$ & $-17,328$ & $-18,207$ \\
\hline Annual percentage change in volume & -4.1 & 7.0 & 6.9 & 11.4 & 5.5 & 4.7 \\
\hline Current account & 14,671 & 8,328 & 4,250 & 7,318 & 15,098 & 17,825 \\
\hline In percent of GDP 1/ & 39.8 & 24.5 & 12.1 & 17.5 & 29.1 & 31.8 \\
\hline External public and publicly guaranteed debt & 0.4 & 0.4 & 0.6 & 0.5 & $\ldots$ & $\ldots$ \\
\hline International reserve assets, of which: & 7,186 & 10,000 & 9,314 & 7,685 & 8,359 & 8,923 \\
\hline Central Bank of Kuwait & 6,577 & 9,268 & 8,455 & 6,744 & 7,451 & 8,015 \\
\hline \multirow[t]{2}{*}{ In months of imports of goods and services } & 7.6 & 9.7 & 8.0 & 5.7 & 5.8 & 5.9 \\
\hline & \multicolumn{6}{|c|}{ (Percentage change; unless otherwise noted) } \\
\hline \multicolumn{7}{|l|}{ Memorandum items: } \\
\hline Exchange rate (US\$ per KD, period average) 3/ & 3.26 & 3.26 & 3.29 & 3.36 & 3.39 & $\ldots$ \\
\hline Nominal effective exchange rate $4 /$ & 4.7 & 5.8 & -0.7 & -6.9 & -6.9 & $\ldots$ \\
\hline Real effective exchange rate $4 /$ & 4.2 & 5.1 & -0.9 & -7.7 & -5.4 & $\ldots$ \\
\hline Credit rating $(\mathrm{S} \& \mathrm{P})$ & $\ldots$ & $\ldots$ & $\ldots$ & $\ldots$ & $\mathrm{A}+$ & $\ldots$ \\
\hline
\end{tabular}

Sources: Data provided by the authorities; and Fund staff estimates.

1/ For 2003, the discrepancy between the savings/investment balance and the current account balance is possibly due to the data being preliminary and may be resolved when the authorities revise the data.

2/ Kuwaiti fiscal year ending March 31. The 2000/01 fiscal year was only 9-month, and the data were obtained by grossing up the 9-month data.

3/ Since January 5, 2003, the exchange rate of the Kuwaiti dinar has been officially pegged to the U.S. dollar at $0.29963 \mathrm{KD} / \mathrm{US} \$(3.33745 \mathrm{US} \$ / \mathrm{KD})$ within a margin not exceeding 3.5 percent on both sides of this parity exchange rate.

4/ For 2004, average for January to October. 
Table 2. Kuwait: Summary of Government Finance, 2000/01-2004/05 1/

\begin{tabular}{|c|c|c|c|c|c|c|}
\hline & $2000 / 01$ & $2001 / 02$ & $2002 / 03$ & $2003 / 04$ & $\frac{\text { Budg. }}{2004 / 05}$ & $\begin{array}{r}\text { Proj. } \\
2004 / 05\end{array}$ \\
\hline & \multicolumn{6}{|c|}{ (In millions of Kuwaiti dinars) } \\
\hline Total revenue & 8,722 & 6,630 & 7,256 & 7,966 & 3,167 & 9,649 \\
\hline Oil and gas & 6,037 & 4,525 & 5,499 & 6,150 & 2,735 & 7,634 \\
\hline Investment income and transfer & & & & & & \\
\hline of profits of public entities $2 /$ & 2,208 & 1,386 & 1,164 & 1,161 & 0 & 1,461 \\
\hline Other current revenue 3 / & 476 & 718 & 567 & 618 & 407 & 529 \\
\hline Capital revenue & 2 & 1 & 26 & 37 & 25 & 25 \\
\hline Total expenditure & 4,283 & 4,796 & 4,890 & 5,454 & 6,145 & 6,207 \\
\hline Current & 3,939 & 4,290 & 4,318 & 4,773 & 5,150 & 5,363 \\
\hline Wages and salaries & 1,573 & 1,637 & 1,709 & 1,825 & 1,939 & 1,939 \\
\hline Goods and services & 985 & 1,061 & 1,196 & $1,436^{4 /}$ & 1,448 & 1,355 \\
\hline Interest on domestic debt $5 /$ & 254 & 203 & 121 & 81 & 37 & 117 \\
\hline Transfers abroad & 91 & 97 & 82 & 63 & 83 & 83 \\
\hline Subsidies and transfers & 1,036 & 1,292 & 1,210 & 1,368 & 1,644 & 1,870 \\
\hline Capital & 344 & 506 & 572 & 681 & 995 & 844 \\
\hline Overall balance & 4,439 & 1,834 & 2,366 & 2,512 & $-2,978$ & 3,442 \\
\hline Overall balance exc. oil rev. & $-1,598$ & $-2,691$ & $-3,133$ & $-3,638$ & $-5,713$ & $-4,192$ \\
\hline Financing & $-4,439$ & $-1,834$ & $-2,366$ & $-2,512$ & 2,978 & $-3,442$ \\
\hline Domestic (net) & -303 & -134 & -351 & -122 & $\ldots$ & -813 \\
\hline Banks & -438 & -169 & -196 & -66 & $\ldots$. & -813 \\
\hline Nonbanks & 135 & 35 & -156 & -55 & $\ldots$. & 0 \\
\hline External & 0 & 0 & 0 & 0 & $\ldots$. & 0 \\
\hline \multirow[t]{2}{*}{ Reserve funds $7 /$} & $-4,136$ & $-1,700$ & $-2,014$ & $-2,390$ & $\ldots$ & $-2,629$ \\
\hline & \multicolumn{6}{|c|}{ (In percent of GDP) } \\
\hline Revenue & 80.2 & 63.1 & 65.2 & 60.6 & 20.3 & 61.9 \\
\hline Oil and gas & 55.5 & 43.1 & 49.4 & 46.8 & 17.6 & 49.0 \\
\hline Investment income & 20.3 & 13.2 & 10.5 & 8.8 & $\ldots$. & 9.4 \\
\hline Other current revenue 3/ & 4.4 & 6.8 & 5.1 & 4.7 & 2.8 & 3.4 \\
\hline Expenditure & 39.4 & 45.6 & 43.9 & 41.5 & 39.4 & 39.8 \\
\hline Current & 36.2 & 40.8 & 38.8 & 36.3 & 33.0 & 34.4 \\
\hline Wages and salaries & 14.5 & 15.6 & 15.4 & 13.9 & 12.4 & 12.4 \\
\hline Goods and noninterest services & 9.1 & 10.1 & 10.7 & 10.9 & 9.3 & 8.7 \\
\hline Interest on domestic and foreign debt & 2.3 & 1.9 & 1.1 & 0.6 & 0.2 & 0.8 \\
\hline Subsidies and transfers & 9.5 & 12.3 & 10.9 & 10.4 & 10.5 & 12.0 \\
\hline Capital & 3.2 & 4.8 & 5.1 & 5.2 & 6.4 & 5.4 \\
\hline Overall balance & 40.8 & 17.5 & 21.3 & 19.1 & -19.1 & 22.1 \\
\hline Non-oil deficit/Non-oil GDP & -29.7 & -48.2 & -53.0 & -58.2 & -83.1 & -61.0 \\
\hline \multirow[t]{2}{*}{ Non-oil primary deficit/Non-oil GDP } & -25.0 & -44.6 & -51.0 & -56.9 & & -59.3 \\
\hline & \multicolumn{6}{|c|}{ (In millions of Kuwaiti dinars, unless otherwise indicated) } \\
\hline \multicolumn{7}{|l|}{ Memorandum items: } \\
\hline $\begin{array}{l}\text { Overall balance (excluding investment } \\
\text { income and profit transfers) }\end{array}$ & 2,231 & 448 & 1,202 & 1,351 & $-2,978$ & 1,982 \\
\hline (In percent of GDP) & 20.5 & 4.3 & 10.8 & 10.3 & -19.1 & 12.7 \\
\hline Average oil export price (in US dollar/barrel) & 23.1 & 21.6 & 23.5 & 27.1 & 15.0 & 32.5 \\
\hline
\end{tabular}

Sources: Ministry of Finance; Central Bank of Kuwait; and Fund staff estimates and projections.

1/ Coverage of budgetary operations includes the operation of the KIA. Data are on an accrual basis.

2/ Excluded from the national budget presentation. Estimated by the Fund staff.

3 / Excludes revenues from utility tariffs (which are included in the national budget presentation), but includes

UN (Iraq) compensations.

4/ Includes the KD 121 million supplementary budget for the emergency spending.

5 / Covers interest payments on the treasury bills and bonds, and on the DCP bonds. Only the latter is included in the national budget presentation.

6/ Includes KD 192 million one-time transfer of the oil windfall to Kuwaiti nationals.

7/ The Reserve Fund for Future Generations (RFFG) and the General Reserve Fund (GRF). 
Table 3. Kuwait: Summary Balance of Payments, 2000-05

(In millions of U.S. dollars)

\begin{tabular}{|c|c|c|c|c|c|c|}
\hline & 2000 & 2001 & 2002 & 2003 & $\frac{\text { Est. }}{2004}$ & $\frac{\text { Proj. }}{2005}$ \\
\hline Current account & 14,671 & 8,328 & 4,250 & 7,318 & 15,098 & 17,825 \\
\hline Goods (trade balance) & 13,025 & 9,196 & 7,241 & 11,012 & 17,843 & 19,754 \\
\hline Exports & 19,476 & 16,246 & 15,363 & 20,695 & 28,310 & 30,864 \\
\hline Oil exports & 18,182 & 14,977 & 14,057 & 19,004 & 25,951 & 28,385 \\
\hline Non-oil exports including re-exports & 1,294 & 1,269 & 1,306 & 1,691 & 2,359 & 2,479 \\
\hline Of which: re-exports & 209 & 203 & 216 & 416 & 780 & 820 \\
\hline Petrochemicals $1 /$ & 761 & 752 & 751 & 865 & $\ldots$ & $\ldots$ \\
\hline Imports & $-6,451$ & $-7,050$ & $-8,123$ & $-9,683$ & $-10,468$ & $-11,110$ \\
\hline Services & $-3,097$ & $-3,693$ & $-4,188$ & $-4,640$ & $-4,818$ & $-4,944$ \\
\hline Transportation & -153 & -372 & -618 & -634 & -650 & -561 \\
\hline Travel & $-2,396$ & $-2,740$ & $-2,902$ & $-3,231$ & $-3,340$ & $-3,525$ \\
\hline Other services & -548 & -581 & -668 & -775 & -828 & -858 \\
\hline Investment income & 6,698 & 4,903 & 3,342 & 3,325 & 4,632 & 5,768 \\
\hline Receipts & 7,315 & 5,428 & 3,708 & 3,610 & 5,041 & 6,504 \\
\hline General government 2/ & 4,704 & 3,673 & 2,780 & 2,795 & 4,033 & 5,376 \\
\hline Other sectors $3 /$ & 2,611 & 1,755 & 928 & 815 & 1,008 & 1,129 \\
\hline Payments & -616 & -525 & -365 & -285 & -409 & -736 \\
\hline General government & -16 & -52 & -13 & -10 & -14 & -26 \\
\hline Other & -600 & -473 & -352 & -275 & -395 & -710 \\
\hline Current transfers $4 /$ & $-1,956$ & $-2,078$ & $-2,145$ & $-2,379$ & $-2,558$ & $-2,753$ \\
\hline Capital and financial account & $-11,555$ & $-3,383$ & $-3,490$ & $-9,901$ & $-14,424$ & $-17,261$ \\
\hline Capital account 5/ & 2,217 & 2,933 & 1,671 & 1,429 & 500 & 100 \\
\hline Financial account & $-13,772$ & $-6,316$ & $-5,162$ & $-11,330$ & $-14,924$ & $-17,361$ \\
\hline Direct investment & 319 & -512 & 161 & 4922 & -300 & -50 \\
\hline Abroad & 303 & -365 & 155 & 4989 & -500 & -350 \\
\hline In reporting country & 16 & -147 & 7 & -67 & 200 & 300 \\
\hline Portfolio investment & $-12,667$ & $-7,448$ & $-3,263$ & $-13,042$ & $-12,000$ & $-14,579$ \\
\hline Assets & $-12,921$ & $-7,369$ & $-3,425$ & $-13,377$ & $-12,426$ & $-14,953$ \\
\hline Liabilities & 254 & -78 & 161 & 336 & 426 & 374 \\
\hline Other investment & $-1,424$ & 1,644 & $-2,059$ & $-3,211$ & $-2,624$ & $-2,733$ \\
\hline Trade credits & -274 & 470 & -405 & -278 & -342 & -425 \\
\hline Loans & -489 & -42 & -270 & -225 & -503 & -594 \\
\hline Currency and deposits & $-1,040$ & 2,055 & $-1,503$ & $-2,355$ & -1820 & -1763 \\
\hline Other & 378 & -838 & 118 & -352 & 41 & 50 \\
\hline Net errors and omissions 6 / & -858 & $-2,131$ & $-1,446$ & 954 & 0 & 0 \\
\hline Overall balance & 2,258 & 2,814 & -686 & $-1,629$ & 674 & 564 \\
\hline International reserve assets (-increase) 7/ & $-2,258$ & $-2,814$ & 686 & 1,629 & -674 & -564 \\
\hline \multicolumn{7}{|l|}{ Memorandum items } \\
\hline Current account/GDP & 39.8 & 24.5 & 12.1 & 17.5 & 29.1 & 31.8 \\
\hline Overall balance/GDP & 6.1 & 8.3 & -2.0 & -3.9 & 1.3 & 1.0 \\
\hline International reserve assets (US\$ millions) & 7,186 & 10,000 & 9,314 & 7,685 & 8,359 & 8,923 \\
\hline Total reserves minus gold & 7,082 & 9,897 & 9,208 & 7,577 & 8,251 & 8,815 \\
\hline Gold (national valuation) & 103.9 & 103.1 & 105.9 & 107.6 & 107.6 & 107.6 \\
\hline In months of imports of goods and services & 7.6 & 9.7 & 8.0 & 5.7 & 5.8 & 5.9 \\
\hline
\end{tabular}

Source: Central Bank of Kuwait; and Fund staff estimates.

1/ Exports of Kuwaiti origin plastics in primary form and manufactured fertilizers.

2/ Kuwait Investment Authority, Kuwait Petroleum Corporation, Kuwait Fund for Arab Economic Development, Public Institute for Social Security, Kuwait Airways Corporation, and Bank of Savings and Credit.

3/ CBK, local banks, investment companies, exchange companies, insurance companies, and the non-financial private sector.

4/ Primarily expatriate workers' remittances.

5/ Includes UN war compensation.

6/ Includes other unclassified private sector flows.

7/ As reported in Table 31 of the Statistical Appendix. 
Table 4. Kuwait: Monetary Survey, 2000-04

\begin{tabular}{|c|c|c|c|c|c|}
\hline End of period & 2000 & 2001 & 2002 & 2003 & 2004 \\
\hline & \multicolumn{5}{|c|}{ (In millions of Kuwaiti dinars) } \\
\hline Foreign assets (net) & 2,778 & 3,306 & 2,930 & 2,467 & 3,603 \\
\hline Central bank & 2,005 & 2,850 & 2,521 & 1,966 & 2,165 \\
\hline Local banks & 773 & 456 & 409 & 500 & 1,438 \\
\hline Domestic assets (net) & 5,385 & 5,902 & 6,716 & 7,935 & 7,919 \\
\hline Claims on government (net) & 2,911 & 2,573 & 2,595 & 2,323 & 1,510 \\
\hline Central bank (net) & -532 & -598 & -354 & -413 & -662 \\
\hline Claims & 0 & 0 & 0 & 0 & 0 \\
\hline Deposits & 532 & 598 & 354 & 413 & 662 \\
\hline Local banks (net) & 3,443 & 3,171 & 2,949 & 2,735 & 2,172 \\
\hline Claims & 3,628 & 3,402 & 3,248 & 3,050 & 2,750 \\
\hline Government debt bonds & 1,491 & 1,294 & 1,006 & 818 & 604 \\
\hline Public debt instruments & 2,137 & 2,108 & 2,242 & 2,232 & 2,146 \\
\hline Other claims & 0 & 0 & 0 & 0 & 0 \\
\hline Deposits & 185 & 231 & 299 & 315 & 578 \\
\hline Claims on nongovernment sector & 5,848 & 6,753 & 7,723 & 9,379 & 10,814 \\
\hline Credit facilities & 5,230 & 6,027 & 6,854 & 8,419 & 9,808 \\
\hline Local investments & 619 & 726 & 870 & 959 & 1,006 \\
\hline Other items (net) & $-3,375$ & $-3,423$ & $-3,602$ & $-3,767$ & $-4,405$ \\
\hline Broad money & 8,163 & 9,209 & 9,646 & 10,401 & 11,522 \\
\hline Money & 1,468 & 1,641 & 2,067 & 2,612 & 2,983 \\
\hline Quasi money & 6,695 & 7,567 & 7,580 & 7,790 & 8,539 \\
\hline \multirow[t]{2}{*}{ Of which: Foreign currency deposits } & 895 & 892 & 904 & 991 & 1,169 \\
\hline & \multicolumn{5}{|c|}{ (Annual percentage change) } \\
\hline Foreign assets (net) & 46.3 & 19.0 & -11.4 & -15.8 & 46.1 \\
\hline Central Bank & 51.9 & 42.2 & -11.6 & -22.0 & 10.1 \\
\hline Local banks & 33.6 & -41.0 & -10.3 & 22.3 & 187.3 \\
\hline Domestic assets (net) & -6.8 & 9.6 & 13.8 & 18.1 & -0.2 \\
\hline Claims on Government (net) & -16.2 & -11.6 & 0.8 & -10.5 & -35.0 \\
\hline Claims on nongovernment sector & 5.4 & 15.5 & 14.4 & 21.4 & 15.3 \\
\hline Other items (net) & -4.0 & -1.4 & -5.2 & -4.6 & -16.9 \\
\hline Broad money & 6.3 & 12.8 & 4.8 & 7.8 & 10.8 \\
\hline Money & 7.0 & 11.8 & 25.9 & 26.4 & 14.2 \\
\hline Quasi money & 6.2 & 13.0 & 0.2 & 2.8 & 9.6 \\
\hline \multirow[t]{2}{*}{ Of which : Foreign currency deposits } & 1.6 & -0.3 & 1.3 & 9.6 & 18.1 \\
\hline & \multicolumn{5}{|c|}{ (Change in percent of beginning broad money stock) } \\
\hline Foreign assets (net) & 11.5 & 6.5 & -4.1 & -4.8 & 10.9 \\
\hline Central bank & 8.9 & 10.4 & -3.6 & -5.7 & 1.9 \\
\hline Local banks & 2.5 & -3.9 & -0.5 & 0.9 & 9.0 \\
\hline Domestic assets (net) & -5.1 & 6.3 & 8.8 & 12.6 & -0.1 \\
\hline Claims on government (net) & -7.3 & -4.1 & 0.2 & -2.8 & -7.8 \\
\hline Claims on nongovernment sector & 3.9 & 11.1 & 10.5 & 17.2 & 13.8 \\
\hline Other items (net) & -1.7 & -0.6 & -1.9 & -1.7 & -6.1 \\
\hline Broad money & 6.3 & 12.8 & 4.8 & 7.8 & 10.8 \\
\hline Money & 1.3 & 2.1 & 4.6 & 5.6 & 3.6 \\
\hline Quasi money & 5.1 & 10.7 & 0.1 & 2.2 & 7.2 \\
\hline Of which : Foreign currency deposits & 0.2 & 0.0 & 0.1 & 0.9 & 1.7 \\
\hline \multicolumn{6}{|l|}{ Memorandum items: } \\
\hline Net domestic credit (annual percentage change) & -3.0 & 6.5 & 10.6 & 13.4 & 5.3 \\
\hline
\end{tabular}




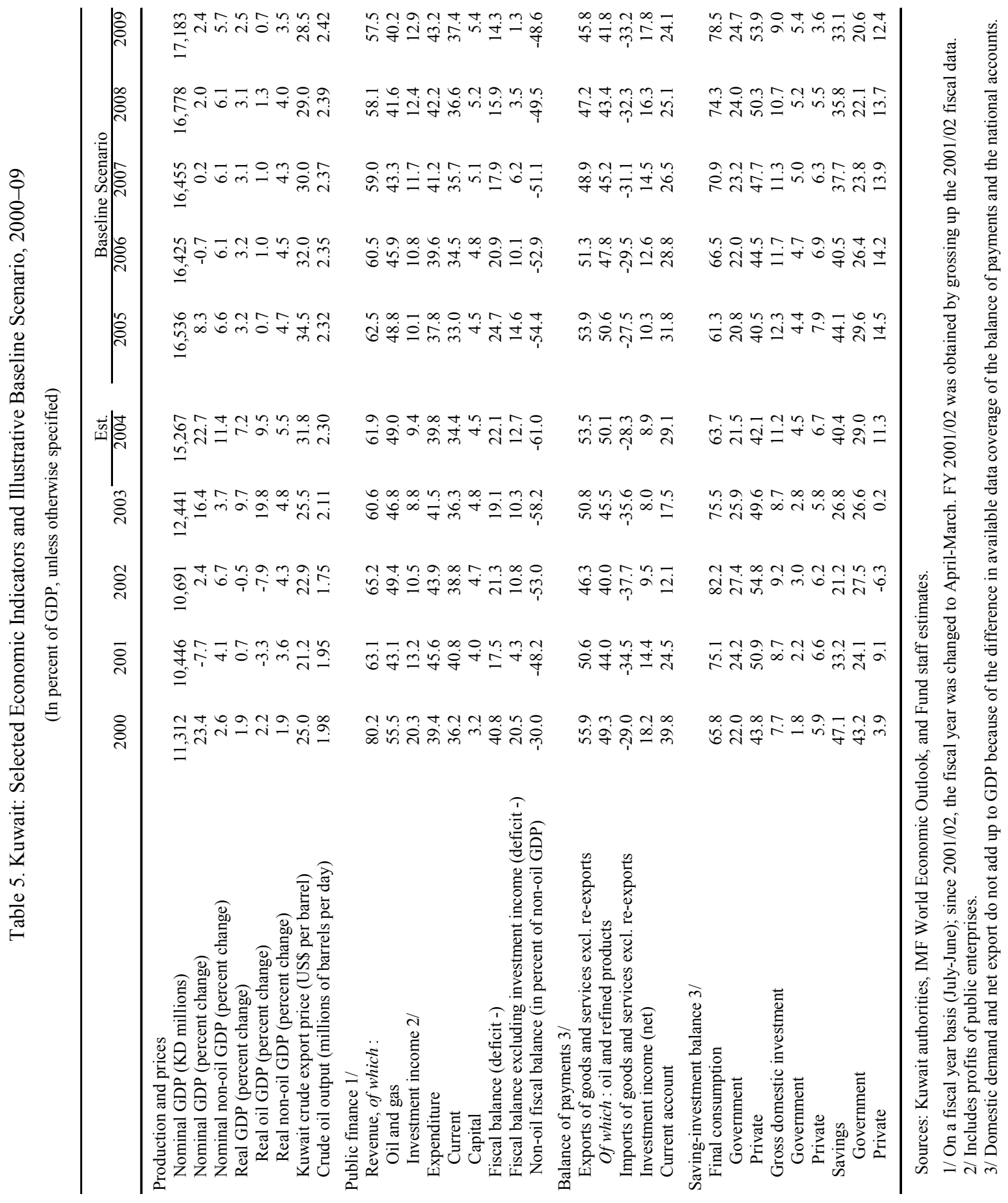


Table 6. Kuwait: Vulnerability Indicators, 2000-04

(In percent, unless otherwise indicated)

\begin{tabular}{|c|c|c|c|c|c|}
\hline & 2000 & 2001 & 2002 & 2003 & $\frac{\text { Est. }}{2004}$ \\
\hline \multicolumn{6}{|l|}{ External solvency indicators } \\
\hline REER (CPI based, period average) & 4.2 & 5.1 & -0.9 & -7.7 & $-5.4^{11 /}$ \\
\hline External debt including private sector (in millions of U.S. dollars) & 9,956 & 11,094 & 12,368 & 12,404 & 12,772 \\
\hline Short-term debt (original maturity) $1 /$ & 4,199 & 5,255 & 4,901 & 5,863 & 6,185 \\
\hline Medium- and long-term debt 2/ & 5,757 & 5,839 & 7,467 & 6,541 & 6,586 \\
\hline External debt/GDP & 27.0 & 32.6 & 35.2 & 29.7 & 24.7 \\
\hline External debt/total exports of goods and services & 46.7 & 61.9 & 72.7 & 54.9 & 42.1 \\
\hline Short-term debt/total exports of goods and services & 19.7 & 29.3 & 28.8 & 25.9 & 20.4 \\
\hline External debt service/total exports of goods and services & 2.9 & 2.9 & 2.2 & 1.3 & 0.8 \\
\hline \multicolumn{6}{|l|}{ Public sector solvency indicators } \\
\hline General government domestic debt/GDP 3/ & 35.0 & 36.0 & 32.5 & 26.4 & $21.1^{12 /}$ \\
\hline Interest payments/total revenue & 2.9 & 3.1 & 1.7 & 1.0 & 1.2 \\
\hline \multicolumn{6}{|l|}{ Distribution of the public domestic debt by holders } \\
\hline Local commercial banks & 86.4 & 85.6 & 91.0 & 90.7 & $88.7^{12 /}$ \\
\hline Other (including nongovernment public institutions) & 13.6 & 14.4 & 9.0 & 9.3 & $11.3^{12 /}$ \\
\hline Oil revenue/total revenue & 69.2 & 68.3 & 75.8 & 77.2 & 79.1 \\
\hline \multicolumn{6}{|l|}{ External liquidity indicators } \\
\hline CBK net foreign assets (in millions of U.S. dollars) & 6,564 & 9,257 & 8,415 & 6,672 & 7,346 \\
\hline CBK gross foreign assets (in millions of U.S. dollars) 4/ & 6,577 & 9,268 & 8,455 & 6,744 & 7,451 \\
\hline In months of imports of goods and services & 6.9 & 9.0 & 7.3 & 5.0 & 5.2 \\
\hline Relative to short-term external debt & 156.6 & 176.4 & 172.5 & 115.0 & 120.5 \\
\hline Relative to M0 & 375.5 & 547.3 & 429.1 & 288.1 & 280.7 \\
\hline Relative to M1 & 136.9 & 173.8 & 122.5 & 76.1 & 73.6 \\
\hline Local banks' net foreign assets (in millions of U.S. dollars) & 2,532 & 1,481 & 1,366 & 1,698 & 4,879 \\
\hline Foreign assets & 6,445 & 6,583 & 8,149 & 8,230 & 11,717 \\
\hline Foreign liabilities & 3,913 & 5,101 & 6,782 & 6,532 & 6,838 \\
\hline Oil exports/total exports & 93.4 & 92.2 & 91.5 & 91.8 & 91.7 \\
\hline \multicolumn{6}{|l|}{ Financial sector indicators } \\
\hline Increase in net bank profits & 20.9 & 9.9 & 0.6 & 21.2 & $16.8^{13 /}$ \\
\hline Ratio of net profits to total bank assets & 2.0 & 2.0 & 1.8 & 2.0 & $2.3^{13 /}$ \\
\hline Ratio of net profits to total shareholders' equity & 17.6 & 18.2 & 17.4 & 18.6 & $20.4^{13 /}$ \\
\hline Banks' capital-asset ratio & 11.5 & 11.2 & 10.4 & 10.7 & $11.3^{13 /}$ \\
\hline Banks risk-weighted capital-asset ratio & 22.2 & 22.0 & 19.7 & 18.4 & $17.3^{13 /}$ \\
\hline Banks' leverage $5 /$ & 8.7 & 9.0 & 9.6 & 9.4 & 9.1 \\
\hline \multicolumn{6}{|l|}{ Financial sector indicators } \\
\hline Banks' liquidity ratio 6/ & 16.3 & 14.8 & 14.0 & 12.9 & 15.7 \\
\hline Ratio of banks' nonperforming loans to total loans & 19.2 & 10.3 & 7.8 & 6.1 & $5.4^{13 /}$ \\
\hline Nonperforming loans from before invasion & 12.8 & 5.1 & 4.8 & 3.6 & $3.1^{13 /}$ \\
\hline Nonperforming loans since liberation & 6.4 & 5.2 & 3.0 & 2.5 & $2.3^{13 /}$ \\
\hline Loan provisions as a proportion of nonperforming loans & 50.1 & 53.7 & 64.3 & 72.4 & $72.4^{13 /}$ \\
\hline
\end{tabular}


Table 6. Kuwait: Vulnerability Indicators, 2000-04

(In percent, unless otherwise indicated)

\begin{tabular}{|c|c|c|c|c|c|}
\hline & 2000 & 2001 & 2002 & 2003 & $\frac{\text { Est. }}{2004}$ \\
\hline \multicolumn{6}{|l|}{ Ratio of bank lending to total domestic credit facilities } \\
\hline Stock market-related & 4.8 & 6.4 & 5.8 & 9.0 & 8.5 \\
\hline Real estate 7/ & 16.3 & 19.3 & 18.9 & 17.0 & 16.4 \\
\hline Total (stock market, real estate) & 21.1 & 25.7 & 24.8 & 26.0 & 24.9 \\
\hline \multicolumn{6}{|l|}{ Ratio of bank lending to banks' own funds } \\
\hline Stock market-related & 15.7 & 22.9 & 22.5 & 37.6 & 39.6 \\
\hline Real estate 7/ & 53.9 & 69.3 & 73.3 & 71.4 & 76.3 \\
\hline Total (stock market, real estate) & 69.6 & 92.2 & 95.8 & 109.0 & 115.9 \\
\hline Banks' interest rate spread 8/ & -0.6 & 0.4 & 0.9 & 0.8 & $0.6^{14 /}$ \\
\hline \multirow[t]{2}{*}{ Investment companies' capital and reserve/total assets } & 37.4 & 31.5 & 31.4 & $\ldots$ & $\ldots$ \\
\hline & \multicolumn{5}{|c|}{ (In millions of Kuwaiti dinars) } \\
\hline Net foreign assets of local banks & 773.3 & 456.1 & 409.3 & 500.4 & $1,437.7$ \\
\hline Net foreign assets of investment companies 9/ & 794.8 & 667.1 & 709.0 & 699.0 & $902.8^{13 /}$ \\
\hline Open foreign exchange position of banks $10 /$ & 38.9 & -34.9 & 74.6 & 84.9 & $72.2^{13 /}$ \\
\hline
\end{tabular}

Source: Central Bank of Kuwait, and Fund staff estimates.

1/ Short-term data are obtained from the joint BIS-IMF-OECD-World Bank database.

2/ Medium- and long-term debt is estimated as a residual.

3/ Treasury bills and bonds, and debt purchase bonds.

4/ Excludes SDRs and IMF reserve position.

5/ Ratio of total liabilities to banks' own funds.

6/ Ratio of liquid assets (cash, central bank current deposits, and treasury bills and bonds) to total assets.

7/ Ratios may be overestimated due to loan classification problems by the local banks.

8/ Calculated as the difference between 3- month deposits rates in KD relative to the 3-month deposit rates in US\$.

9/ Equals nonresident assets minus nonresident liabilities, excluding own funds.

10/ A (-) sign indicates a short position.

11/ Average for January to October 2004.

12/ As of end-June 2004.

13/ As of end-September 2004.

14/ Average January-September 2004. 


\section{KUWAIT}

\section{FUND RELATIONS}

(As of December 31, 2004)

I. Membership Status: Joined September 13, 1962

Article VIII on April 5, 1963

II. General Resources Account:

Quota

Fund holdings of currency

Reserve position in Fund

III. SDR Department:

Net cumulative allocation

Holdings

\author{
SDR Million \\ $1,381.10$ \\ 922.16 \\ 458.94
}

SDR Million

26.74

117.07
\% Quota

100.00

66.77

33.23

\% Allocation

100.00

437.74

IV. Outstanding Purchases and Loans: None

V. Financial Arrangements: None

VI. Projected Obligations to Fund: None

\section{Exchange Rate Arrangement:}

Since January 1, 2003, the Kuwaiti dinar has been pegged to the U.S. dollar. The decision to peg the dinar to the U.S. dollar reflected plans to create a single currency for the six members of the Cooperation Council for the Arab States of the Gulf (GCC). Previously, the Kuwaiti dinar was pegged to a U.S. dollar-dominated basket of currencies. The central bank normally maintains buying/selling rates for the U.S. dollar at one-sixteenth of 1 percent on either side of the Kuwaiti dinar exchange rate: US\$1=KD 0.29470 as of end-October 2004.

\section{Article IV Consultations:}

The latest Article IV consultation was completed by the Executive Board on February 9, 2004. The staff report and the associated Statistical Appendix were issued in July 2004, Country Report No. 04/186 and 04/197, respectively.

\section{FSAP Participation}

A FSAP exercise was conducted in September 2003 in order to assess three international standards and codes (banking, securities, and AML/CFT). A FSSA report was discussed by 
the Executive Board along with the staff report for the 2003 Article IV consultation and was issued in May 2004, Country Report No. 04/151.

\section{Technical Assistance:}

FAD Advisory mission

MAE Advice on bank report forms

FAD Advice on fiscal reform

STA Multi-topic statistics mission

FAD Budget advisor

MED Macroeconomic model

MAE Early warning system and banks supervision

STA Balance of payment statistics

MAE Monetary policy instruments

MAE Early warning system

MAE Monetary policy issues

MAE Bank supervision

INS Financial programming

MAE Bank deposit scheme

STA Seminar on GDDS

STA National Accounts and Price Statistics

FAD Restructuring Budget Processes

FAD A Program for Tax Reform

MFD/LEG Bank Insolvency
April 1992

October 1992

February-March 1993

April-May 1994

September 1993-

October 1994

September 1996

May 1997

November 1998

November 1998

December 1998

March 1999

April 1999

April 1999

October/November 1999

February 2000

June 2001-June 2002

January/February 2002

December 2002

October 2004

\section{Resident Representative: None}

XII. Kuwait has consented to the quota increase under the Eleventh General Review of Quotas; it has accepted the Fourth Amendment of the Articles of Agreement. 


\title{
KUWAIT
}

\section{Relations with the World Bank Group}

\author{
As of January 13, 2005
}

An annual Technical Cooperation Program Agreement was first signed in the spring of 2002 and renewed in June 2003 for another year. However, it expired last March and was not renewed, due to organizational changes within the government. As a result, the technical cooperation program slowed considerably. Currently, two projects are ongoing:

1. Kuwait Education Indicators and Assessment Project (KEIAP): The Ministry of Education (MOE) launched the Kuwait Education Indicators and Assessment Project (KEIAP) in September 2003. The main accomplishments to date include the following:

- An Education Indicators Report, the first of its kind in Kuwait, has been completed and is being published;

- Testing instruments for the national assessment for grades 4 and 8 have been developed and pilot testing has been completed;

- Participation in the 5-year cycle of the international Program in Reading Literacy Studies (PIRLS) started on time;

- Preparations are well underway for rejoining the Trends in Mathematics and Science Studies (TIMSS) (starting February 2005); and

- The development of an Education Information Management System (EMIS) has been launched.

These accomplishments provide a sound basis for diagnosing the issues in the education system, designing education reform and monitoring progress. This is the second year of a six-year program.

2. International Conference on Challenges of Economic Development for the GCC Countries: The Bank will provide four keynote speakers to present their papers at the conference-taking place in January 29-31, 2005.

3. There is renewed interest in re-activating the agreement, given interest from various government units for Bank support, such as ppps/BOTs.

\section{Past Activities:}


- $\quad$ Post-war reconstruction: In January 1991, the Bank submitted to the government a report, Kuwait: Emergency Relief Program that included action plans and a framework for reconstruction following liberation.

- Privatization: The World Bank has carried out a study of privatization strategies in the industrial, services, health, telecommunications, power, ports, and transportation sectors, (World Bank, Kuwait: A Privatization Strategy, Washington, 1993); assisted delegations from the National Assembly and the KIA in studying worldwide experience in the implementation of privatization (1994-97); and provided assistance on the draft and privatization law. In addition, the World Bank has been advising the Kuwait Investment Authority (KIA) on the divestiture phase of the privatization program.

- $\quad$ Development strategy: The Country Economic Memorandum (CEM) prepared in 1995 focused on several issues (i) the role of government and public sector productivity; (ii) fiscal policies and public saving; (iii) welfare and subsidization; and (iv) the labor market and employment policies. The World Bank also provided the National Assembly with its views on the draft Five-Year Plan (1996), in addition to providing advice on the draft reform plan prepared by the Higher Committee for Economic Development and Reform over the period 1998-99. Also, the World Bank in collaboration with Kuwait's Higher Planning Council, and Kuwait University has in early March 2001 completed a study entitled "Energizing the Private Sector" in Kuwait. In 2002, the World Bank is conducting various missions in land policy, power sector reform, telecommunications, transportation, and tourism to identify areas where technical assistance might be needed.

- Reform implementation: Based on this recent study on "Energizing the Private Sector," as well as other technical assistance activities, the Government of Kuwait has requested World Bank assistance in implementation of the various reform initiatives, including the institutional set-up for an implementation agency. The Government of Kuwait and the World Bank are currently exploring mechanisms for more World Bank technical assistance involvement in this regard.

- Investment environment: The World Bank's recent technical assistance relationship with the Kuwaiti authorities has concentrated on enhancing the investment environment, with work on the FDI law, identification of policy and administrative impediments to investment, and development of a competition law and policy. A presentation was made on investment promotion, investment climate, and FDI regulations in 2002. Further, the World Bank initiated the FDI Bylaw and provided technical assistance on the negative restricted list.

- Public awareness: As a first step to support the Economic Reform Program, the Bank began managing on behalf of the government a Public Awareness Campaign for its reform agenda in April 2001. 
- Transparency and anti-corruption: At the request of the government, a scoping mission was conducted in September 2002. One central objective of the mission was to develop the Terms of Reference (TORs) and identify the key institutions to be involved. The Council of Ministers assigned the responsibility for developing the Transparency and AntiCorruption Strategy to the Citizens Services and Governmental Bodies Assessment Agency. A working group was also formed based on Bank recommendation. Last June, a Bank mission produced a report, "Toward a Comprehensive Transparency and Anti-Corruption Strategy in Kuwait." The report proposed a number of measures that could be initiated in the short term, as well as a framework that encompassed the main elements of a long-term strategy. Next step is to organize a high-level workshop on international experience and strategies currently planned for early 2004.

- Small business promotion: The World Bank has provided technical assistance, which has led to the establishment of the Kuwait Small Projects Development Company (KSPDC). The World Bank is currently advising KSPDC on its operations.

- Labor market: The World Bank, in partnership with Kuwait Institute for Scientific Research (KISR), carried out a labor market study. The study includes a household survey, and an employee/employer survey. The study was conducted at the request of the Higher Committee for Economic Reform and Development and was completed in January 1999. In March 1999, a presentation of the main recommendations of the study was made to the government. The presentation was attended by three ministers, namely Finance, Planning, and Education. Some recommendations of the study were proposed by the government for legislative approval.

- $\quad$ Employment generation: As a follow up to the Labor Market Study, the government requested Bank support in creating private sector jobs for Kuwaitis. A Bank mission visited Kuwait in late August 2003 to develop the Terms of Reference for this activity.

- $\quad$ Education Sector Reform: Following the successful completion of "Education Expenditure Analysis" study, the government sought Bank assistance in implementing the recommendations. It was agreed to focus on these issues: (i) indicators for general education system; (ii) introducing program budgeting; and (iii) carrying out more in-depth analysis on the financing issues and of the costs at school level. This is expected to be carried out in four phases. Phase one, which includes development of indicators, has started and a mission visited Kuwait in late last June. A larger mission visited Kuwait in September 2003 to continue the development of indicators and begin work on program budgeting for education.

- Kuwait health sector: The government recently requested Bank support in assessing the general performance of the health sector and in identifying areas of potential reform, and missions were sent in October 2002 and January 2003. The study (June 2003) provided a general overview of the main issues facing the health sector plus special coverage of five priority areas identified by the government: (i) developing the National Health Accounts 
(NHA), and financing the expatriate health insurance system; (ii) hospital accreditation and quality; (iii) regulation of private health insurance; (iv) assessing hospital efficiency; and (v) program budgeting for the health sector.

- $\quad$ Telecommunications: The Bank received a request from the government in 2002 to develop a Sector Reform Strategy and an implementation action plan. Both have been completed. Recently the government appointed KMPG as advisor on sector reform. Bank will continue to advise government on strategic sector reform issues and help supervise their advisors.

- $\quad$ Power and water strategy: Two draft reports, one on possible LNG options and the other on reforms in the power and waters sector, were submitted to government for comments in early August. The next steps include several tasks: (i) developing the government's vision for the development of the electricity and water sectors; (ii) working out key principles for a legal and regulatory framework and the role for an independent regulatory agency; (iii) determining options for industry restructuring; (iv) discussing various options with key stakeholders; and (v) working out an implementation plan.

- $\quad$ Concessions/BOT: Based on the Concessions Study submitted in early 2002, implementation steps for the Build-Operate-Transfer (BOT) were sent to the government. In addition to addressing the background of the BOT issue, the note identified the required decisions and responsibilities of the various ministries and departments, and included TORs for a BOT Manager and a Value-for-Money Committee.

- $\quad$ Public private partnerships: The project is in the early stages of being defined with the government- (with its focus on its scope and plan of action. The government is considering combining current Concessions/BOT activity with the planned PPP project.

- $\quad$ Land Transport Reform: In July 2002, Kuwait launched an initiative to explore options for reforming its public transport sector, and requested Bank assistance in a Land Transport Sector Reform project consisting of two phases. Phase I (completed August 2002) addressed sector shortcomings in policy, strategy, regulations, and service. Phase II (completed August 2003) recommended interventions, the institution of a "Land Transport Regulatory Authority" to focus on near term needs and private sector participation. The next steps will be to finalize the regulatory strategy and decrees; structure future industry including Public Transport Corporation (KPTC); and prepare a transition package for privatization.

- Bubyan Port Strategic Assessment: This pre-feasibility study was requested in July and implemented on an accelerated basis. Consultants provided their draft final report. Project was completed in September 2003.

- Land Policy: Land management in Kuwait is in transition. A review of the existing situation in the land and real estate was prepared. The review identified barriers for more 
productive and efficient use of urban land and set out an action plan for the sector. The review and action plan were submitted in October 2002.

- Housing Policy: As a follow up to the work done on land policy, a study on housing subsidies was conducted by the Bank. A draft report entitled "A Study of the Housing Benefits Program" was delivered to government for comments last May.

- $\quad$ Competition Policy: Work began in July 2002 and included: (a) preliminary assessment of laws and policies in place as they interface with or impact competition policy; and (b) provision of a draft outline of the type of competition law/policy that Kuwait may wish to consider. The report was finalized in October 2002, and the letter of invitation and the TOR for law firms to engage in the drafting of the competition law/policy were sent in January 2003.

- General public reform: The World Bank has been advising government on various reform initiatives, and has provided ad hoc technical assistance on various topics. In November 2000, the Bank finalized an Evaluation of the Offset Program in Kuwait, which assessed the current structure and presented options for reform. As for ad hoc issues, the Bank made a presentation to high-level decision makers on WTO issues and how Kuwait can benefit from its membership in WTO. 


\section{KUWAIT}

\section{STATISTICAL ISSUES}

\section{National Accounts and Production}

The Central Statistical Office (CSO) has prepared estimates of GDP at both current and constant prices through 2003 (the 2003 estimates are still provisional). Recent improvements of national accounts includes: change of the base year for the constant price data from 1984 to 1995; and improvements in the estimates of value-added for subsidized-goods and services of the public utilities sector through the use of input costs (the household expenditure survey was used previously). The estimates of GDP have been published at the Central Statistical Office website. Starting from the final 2002 data, further improvements will be made to national accounts reflecting the adoption of the 1993 SNA, a sampling frame based on the establishment survey (2002), and the expansion of the coverage of questionnaires. Continued progress, especially in the estimation of value-added for the oil sector, requires the dedication of adequate resources and improved coordination between the Ministries of Planning, Oil, and Finance. STA has provided technical assistance to the Ministry of Planning to improve national accounts and price data. A resident statistics expert was attached to the Ministry of Planning from June 2001 to June 2002. It would be useful if the Central Bank of Kuwait (CBK) would publish oil sector information in the Quarterly

Statistical Bulletin pertaining to output, refining, domestic consumption, export price for crude and refined products and the domestic price of petroleum products. These data are readily available from the Ministry of Oil.

\section{Price Statistics}

The household expenditure survey (2000) has been completed, and a revised basket of goods and services for the consumer price index (CPI) was finalized by the end of 2001. Improved monthly CPI based on a revised basket has been published in monthly CPI bulletins with about a two months lag. The wholesale price index (WPI) needs to be revised to a more modern statistical measure, such as a producer price index (PPI), which is also more useful for national accounting needs. Also, consideration should be given to compiling data on wage rates and developments in the private sector.

\section{Government Finance Statistics}

Kuwait reports annual GFS data for publication in the Government Finance Statistics Yearbook (GFSY) and monthly GFS data for publication in IFS. The GFSY data, however, are reported with a substantial lag (the latest data reported in 2004 is for 1999). The major components of its extrabudgetary revenues (investment income and transfers of profits of public institutions), extrabudgetary expenditures (interest on foreign debt and treasury paper), and financing operations conducted by two reserve funds are not reported. Data on 
investment income, and on interest on foreign debt and treasury paper, however, are usually provided to Article IV consultation missions. The authorities have made some progress in fiscal data presentation, but the lack of a suitable classification of data on the execution of the budget remains a constraint on monitoring effectively fiscal developments during the year. Moreover, data on the operations of the Public Institute for Social Security are not made available. Much of the weaknesses in the fiscal accounts stem from the limitations on the sharing of information between various government agencies. STA has indicated to the authorities that operations of the two reserve funds should be classified as part of government as they perform activities for public policy purposes (management of debt and assets, and financing of the budget). The authorities have also been briefed on the IMF's ongoing work to enhance the transparency of fiscal accounts and presentations detailed in the "Code of Good Practices on Fiscal Transparency" and were encouraged to adopt some of the practices recommended in the Code. According to the FAD report entitled "Restructuring Budget Processes" which was finalized in March 2002, the weakest part of the Kuwaiti Public Expenditure Management (PEM) system is the accounting system.

\section{Money and Banking Statistics}

Money and banking data are reported on a regular and timely basis. Coverage in IFS of the data on deposit money banks and other banking institutions from January 1981 onward was revised according to recommendations of the 1994 STA multi-sector mission. On an issue noted by that mission, it was clarified that the Savings and Credit Bank (SCB) does not accept transferable deposits from the public.

\section{Balance of Payments Statistics}

Kuwait's balance of payments data have substantially improved, in both coverage and methodology. Since the beginning of 1997, the CBK has compiled and disseminated detailed annual data in accordance with the methodology of the BPM5. Quarterly balance of payments and an annual statement of Kuwait's international investment position (IIP) have also been compiled since 1997 by the CBK and provided to Article IV consultation missions. Partial IIP data submitted to STA exclude foreign assets of other government agencies, and are not in BPM5 format. Data on capital flows of the nonfinancial private sector (including foreign direct investment abroad and portfolio investment abroad) are currently not being compiled but measures are being taken (including collaboration between the CBK and the Tax Department of the Ministry of Finance) to correct this omission (which has led to a large "errors and omissions" item in the BOP statistics). Enhancements have been made in the estimation of travel services, but further improvements are needed in compilation practices and in the estimation of data on several service items and private transfers. During recent discussions (October 2004) between STA and the Central Bank of Kuwait, it was agreed that Kuwait should aim to participate in the Fund's 2004 Coordinated Portfolio Investment Survey (CPIS) with a coverage limited to the financial sector. 


\section{Data dissemination}

Kuwait is one of the first GDDS partcipants, and most of its metadata were last updated in the Fund's DSBB in October 2002. The CBK has established its own webpage, which contains the following data that are made available online to the public: money and banking (monthly); balance of payments (annually); trade balance (monthly); exchange rate (average, monthly); GDP by sector and expenditure at current and constant prices (annually); public finance (selected data are available monthly); CPI and WPI (monthly with about a threemonth lag); and securities market indicators (quarterly). Similarly, the Ministry of Planning has constructed a webpage where the CSO, publishes data on national accounts, prices, and other related statistics. The Ministry of Finance's webpage includes elaborated data for the actual and estimated budget. In addition, the KIA's webpage provides data on stock market indices, volume and value of securities traded, as well as privatization schedules and other related information. 


\section{KUWAIT: TABLE OF COMMON INDICATORS REQUIRED FOR SURVEILLANCE}

AS OF JANUARY 31, 2005

\begin{tabular}{|c|c|c|c|c|c|}
\hline & $\begin{array}{l}\text { Date of } \\
\text { latest } \\
\text { observation }\end{array}$ & $\begin{array}{l}\text { Date } \\
\text { received }\end{array}$ & $\begin{array}{c}\text { Frequency } \\
\text { of } \\
\text { Data }^{1}\end{array}$ & $\begin{array}{l}\text { Frequency } \\
\text { of } \\
\text { Reporting }\end{array}$ & $\begin{array}{l}\text { Frequency } \\
\text { of } \\
\text { publication }\end{array}$ \\
\hline Exchange Rates & $01 / / 05$ & $02 / 05$ & M & M & M \\
\hline $\begin{array}{l}\text { International Reserve Assets and Reserve Liabilities } \\
\text { of the Monetary Authorities }{ }^{2}\end{array}$ & $12 / 04$ & $01 / 05$ & M & M & M \\
\hline Reserve/Base Money & $01 / 05$ & $02 / / 05$ & M & M & M, Q \\
\hline Broad Money & $01 / 05$ & $02 / 05$ & M & M & M, Q \\
\hline Central Bank Balance Sheet & $01 / / 05$ & $02 / 05$ & M & M & $\mathrm{M}, \mathrm{Q}$ \\
\hline Consolidated Balance Sheet of the Banking System & $12 / 04$ & $02 / 05$ & M & M & M \\
\hline Interest Rates & $01 / 05$ & $02 / 05$ & M & M & M \\
\hline Consumer Price Index & $09 / 04$ & $01 / 05$ & M & M & M \\
\hline \multicolumn{6}{|l|}{$\begin{array}{l}\text { Revenue, Expenditure, Balance and Composition of } \\
\text { Financing - General Government }\end{array}$} \\
\hline $\begin{array}{l}\text { Revenue, Expenditure, Balance and Composition of } \\
\text { Financing-Central Government }\end{array}$ & FY2003/04 & $12 / 04$ & $A^{4}$ & A & $\begin{array}{c}\text { Not } \\
\text { published } \\
\text { on Fund } \\
\text { standards }\end{array}$ \\
\hline $\begin{array}{l}\text { Stocks of Central Government and Central } \\
\text { Government-Guaranteed Debt }\end{array}$ & $12 / 04$ & $01 / 05$ & M & M & M \\
\hline External Current Account Balance & 2003 & $08 / 04$ & A & A & $\mathrm{A}$ \\
\hline Exports and Imports of Goods and Services & $09 / 03$ & $10 / 04$ & M & M & Q \\
\hline GDP/GNP & 2003 & $12 / 04$ & A & A & A \\
\hline Gross External Debt ${ }^{5}$ & 2003 & $12 / 04$ & A & A & A \\
\hline
\end{tabular}

${ }^{1}$ Daily (D), Weekly (W), Monthly (M), Quarterly (Q), Annually (A); NA: Not Available

${ }^{2}$ Central Bank of Kuwait only.

${ }^{3}$ Fiscal year data only.

${ }^{4}$ Higher frequency data available only in national format.

${ }^{5}$ Primarily private sector; except for a small volume of trade credits, Kuwait has no public external debt. 


\section{Statement by the IMF Staff Representative April 25, 2005}

This statement provides information on recent developments in Kuwait that has become available since the staff report was circulated to the Executive Board on March 8, 2005. The new information does not change the thrust of the staff appraisal.

Oil price. After the issuance of the staff report, the WEO oil price projection was revised upward. The upward revision to the oil price projection used in the staff report is significant, ranging between \$9-11 per barrel over the medium term (2005-09). As a result, both the fiscal and the external current account balances are projected to register surpluses that are much larger than those reported in the staff report. The overall fiscal surplus is now projected to be 34 percent of GDP in 2005/06, compared with 24.7 percent of GDP reported in the staff report. The external current account surplus is also projected to be 8.5 percentage points higher at more than 40 percent of GDP in 2005. On the assumption that oil prices will remain firm over the medium term, the average fiscal and current account surpluses are projected to be close to 30 percent of GDP and 40 percent of GDP, respectively, during 2006-09.

Oil production and investment in the oil sector. As a key participant in the oil market, Kuwait continues to play an important role in contributing to oil market stability and responded to the fast growing global demand for oil by increasing output. In March 2005, Kuwait produced 2.6 million barrels per day (bpd), about 0.4 million bpd above its current OPEC output quota and recent statements by the authorities indicate that actual production could be increased to 2.75-2.8 million bpd by the end of 2005, if warranted by market conditions.

Monetary developments. Credit to the private sector has slowed down, as expected, following the introduction of the 80 percent ceiling (to be fully effective in July 2005) on the credit (net of provisions) to deposits ratio in July 2004. Credit to the private sector decelerated to an average annual rate of 7.4 percent during the period August 2004-March 2005 , compared with an average annual growth rate of 23.2 percent during January 2003July 2004. At the same time, commercial banks' deposit base increased at an annual rate of 18.9 percent since the introduction of the ceiling (compared with an annual rate of 9.4 percent in the previous 19 months). As a result, the ratio of credit to the private sector to total deposits declined from 87 percent in July 2004 to 81.3 percent in March 2005. As anticipated, banks shifted their asset composition, channeling the non-loanable portion of the increase in deposits toward foreign assets. Consequently, the net foreign assets (NFA) of the commercial banks increased by 107 percent since the introduction of the ceiling to more than US $\$ 5$ billion by end-March 2005. Since interbank funding is not eligible for the purpose of meeting the new ceiling, interbank deposits declined by 78 percent during the period August 2004 through March 2005. The Central Bank of Kuwait raised its discount rate by 25 basis points to 5.25 percent on March 23, 2005 in line with the increase in the U.S. Federal Funds rate. 
Stock market developments. The Kuwait stock exchange index witnessed a further increase of 33 percent in 2005 (by April 17, 2005), in the fifth year of the ongoing bull market. The sharp increase in the stock price index is a regional phenomenon, supported by continued growth in corporate profitability, record high oil prices, an improved economic outlook, and higher budgetary outlays. 


\section{INTERNATIONAL MONETARY FUND}

Public Information Notice

EXTERNAL

RELATIONS

DEPARTMENT

Public Information Notice (PIN) No. 05/63

FOR IMMEDIATE RELEASE

May 13, 2005

International Monetary Fund

$70019^{\text {th }}$ Street, NW

Washington, D. C. 20431 USA

\section{IMF Executive Board Concludes 2005 Article IV Consultation with Kuwait}

On April 25, 2005, the Executive Board of the International Monetary Fund (IMF) concluded the Article IV consultation with Kuwait. ${ }^{1}$

\section{Background}

Kuwait's macroeconomic performance strengthened further in 2003 and 2004 reflecting sharply higher oil prices and production. Real GDP grew at an average annual rate of 8.5 percent during this period, its highest pace in the preceding decade and a half. The rebound was also supported by the spillover effects of the renewed trade relations with Iraq. After taking into account the terms-of-trade gains, per capita income increased by 34.5 percent over the two-year period. Inflation and the rate of unemployment remained low at less than 2 percent and 3.5 percent, respectively. The Kuwaiti stock price index more than doubled in 2003 , and increased further by 34 percent in 2004, reflecting higher corporate profits, an improved economic outlook and abundant liquidity.

The central government budgetary position remained strong in 2003/04 and 2004/05 due to significantly higher oil revenues, with annual fiscal surpluses at about 20 percent of GDP.

The stance of fiscal policy was expansionary, as a large part of the higher oil revenue was spent on various government programs. Most of the fiscal surplus was transferred to the Reserve Fund for the Future Generation and the General Reserve Fund, ensuring the most rapid asset buildup since the 1990 Gulf war.

Broad money growth accelerated to 7.8 percent in 2003, keeping pace with increases in demand and supported by a rapid increase in private sector credit (21 percent) in an environment of

\footnotetext{
${ }^{1}$ Under Article IV of the IMF's Articles of Agreement, the IMF holds bilateral discussions with members, usually every year. A staff team visits the country, collects economic and financial information, and discusses with officials the country's economic developments and policies. On return to headquarters, the staff prepares a report, which forms the basis for discussion by the Executive Board. At the conclusion of the discussion, the Managing Director, as Chairman of the Board, summarizes the views of Executive Directors, and this summary is transmitted to the country's authorities.
} 
record low interest rates and strengthened domestic economic activity. Monetary conditions tightened in the second half of 2004 , as a consequence of the increase in interest rates in line with the rise in the U.S. federal funds rate and the introduction of a ceiling on the credit to deposit ratio. The ceiling was imposed to address prudential concerns regarding the rapid expansion of credit to the private sector over the last three years without a parallel increase in bank deposits. Kuwaiti banks are well capitalized and liquid. The capital adequacy ratio remained comfortable (17.3 percent as of end-September 2004), well above its minimum regulatory level (12 percent). Asset quality improved further and net bank profits and returns on equity also increased significantly. Progress was also made in strengthening the financial sector institutional framework.

With higher oil export receipts, the external current account surplus more than doubled over the two-year period to 29 percent of GDP in 2004. Exports grew at an annual rate of 33.6 percent due to a surge in oil and non-oil exports, the latter supported by a sharp increase in exports and reexports to Iraq. As in the past, much of the current account surplus was invested abroad by both the public and private sectors. External reserves of the Central Bank of Kuwait remained at comfortable levels. The depreciation of the U.S. dollar against other major currencies and the low inflation in Kuwait have contributed to a depreciation of the dinar by 9 percent in real effective terms during January 2003-October 2004, enhancing the competitiveness of non-oil exports.

Progress has been made on the structural reform front, albeit at a slow pace. The Foreign Investment Law and the associated by-laws are in place, allowing foreigners to own up to 100 percent of Kuwaiti companies in listed sectors. A draft Privatization Law and an amendment to the Tax Law to lower the corporate income tax that applies only to foreign companies from 55 percent to 25 percent are awaiting parliamentary approval. The authorities allowed private sector participation in sectors previously dominated by the public sector. The Kuwaitization policy has been in place since October 2003, entailing training of unskilled Kuwaiti nationals and increasing the proportion of Kuwaitis employed in the private sector by establishing targets (proportional to the workforce) that the nongovernment companies should observe.

\section{Executive Board Assessment}

Executive Directors agreed with the thrust of the staff appraisal. They commended the authorities for Kuwait's strong economic rebound and a further strengthening of the macroeconomic position in 2004. The fastest pace of economic expansion since the 1990 Gulf-war, combined with the oilrelated terms-of-trade gains, has boosted per capita income and helped build up assets for future generations at a record pace. Directors agreed that, with oil prices likely to remain firm over the medium term, Kuwait's medium-term outlook has improved and is likely to remain favorable, supported by large fiscal and current account surpluses, and low inflation. They observed that generating employment opportunities for the fast-growing Kuwaiti labor force in the domestic private sector and diversifying the structure of the economy are the major medium-term challenges for Kuwait.

Directors encouraged the Kuwaiti authorities to accelerate the pace of structural reforms to further open up the economy for private sector investment in order to address the country's medium-term challenges. Directors welcomed the authorities' awareness of these challenges and their commitment to addressing them, and encouraged them to build the necessary internal 
consensus. They welcomed the authorities' intention to take advantage of the improved security situation and the opportunities created by reopened economic relations with Iraq, and to reposition Kuwait in its traditional role as a gateway to regions in the north and east.

Directors encouraged the authorities to allow the private sector to take a leading role in the associated infrastructure investment projects. In this context, they urged an expeditious passage of the Privatization Law and the amendment to the Tax Law awaiting Parliamentary approval, and a simultaneous broadening of private sector participation in primarily public sector dominated activities. Directors noted that market-based pricing of publicly-provided goods and services could help foster private sector activity, ensure efficient resource allocation, and reduce their burden on the budget.

Directors commended the authorities for the large overall fiscal surpluses recorded in recent years, but expressed concern about the pace of expenditure growth-including the rise in the wage bill-that might be difficult to reverse if that became necessary. They also noted with concern the consequent sharp increase in the non-oil fiscal deficit. Directors observed that increasing the relative size of the public sector undermines the authorities' stated objective to increase the role of the private sector in the economy.

Directors urged the authorities to reduce significantly the non-oil deficit, as a cornerstone of the authorities' medium- and longer-term fiscal strategy. They called for a better targeting of subsidies, putting in place strict controls on new hiring, and not using the public sector as the "employer of last resort." Directors underscored the importance of efficient management of Kuwait's large and fast-growing savings funds and protecting the investments for Kuwait's longterm fiscal sustainability. They therefore welcomed the authorities' intention to push forward reforms aimed at reducing the role of the state in the economy, including its employment role. Directors also strongly supported the authorities' plans to implement a three-year rolling budget by $2006 / 07$ and to strengthen budget and expenditure management. To boost non-oil revenues, several Directors recommended tax reforms in the context of the planned Gulf Cooperation Council union, including the eventual introduction of a value added tax.

Directors commended the authorities for their prudent conduct of monetary policy, which has supported the exchange rate peg and contributed to a remarkable degree of price stability. They noted that the strong non-oil export growth and the recent significant depreciation of the dinar in real effective terms also indicate that the economy remains competitive. Directors supported the authorities' intention to keep the exchange rate peg unchanged until the Gulf Cooperation Council monetary union is established, and to remain open to the choice of the exchange rate regime under the planned monetary union.

Directors noted that the continued rapid expansion of credit for the last three successive years and the strong surge in stock prices, although partly backed by strong economic fundamentals, has posed some risks to the financial system. They agreed that the authorities are rightly concerned about the potential systemic impact of domestic or external shocks on the stability of the financial system, and that they have to implement some precautionary steps to stem the unsustainable pace of credit expansion. Directors observed, however, that the limit on the loans to deposit ratio introduced by the authorities to contain credit expansion in line with the expansion of the banks' deposit base, would constrain market-based operations. Accordingly, they welcomed the authorities' intention to abolish the ceiling on banks' loans to deposit ratio once 
domestic credit expansion stabilizes. Directors also encouraged the authorities to address the potential risks to the financial system through strengthening of risk-based prudential ratios.

Directors commended the authorities for their effective supervision of the banking system, which has resulted in the development of financially sound, well-managed, and profitable institutions. They noted the substantial progress achieved in further liberalizing the financial system and in strengthening the prudential regulations and supervision, including through implementation of some of the Financial Sector Assessment Program recommendations. While taking note of these significant steps, Directors urged the authorities to secure at the earliest the legal basis for the independence of the capital market authority, the insurance supervision authority, and the Central Bank of Kuwait's supervisory authority. On AML/CFT issues, Directors welcomed the ongoing progress, including the amendments to the regulatory framework that have enabled the sharing of information with foreign counterparts.

Directors emphasized that generating employment for the fast growing Kuwaiti labor force is the most important economic challenge for Kuwait. They supported the authorities' labor market reform strategy aimed at training and providing incentives for development of skills needed by the private sector. However, they urged the authorities to continue applying the Kuwaitization policy flexibly so that the competitiveness and profitability of the private sector are not adversely affected. They stressed the importance of promoting market-based wage flexibility for the Kuwaiti workforce in order to facilitate the integration of the segmented labor markets.

Directors welcomed the progress made in compilation and dissemination of Kuwait's economic statistics. They urged the authorities to reduce the delays in collection and reporting of national income, price indices, and customs data. Directors encouraged the authorities to adopt, in coordination with other GCC countries, common data standards across all sectors as a step toward establishing convergence criteria for the planned monetary union. A few Directors also noted the importance of improving the timeliness and transparency of petroleum-related data.

Directors expressed their appreciation to the Kuwaiti authorities for their generous financial assistance to developing countries, including through the HIPC Initiative, as well as for Kuwait's role in stabilizing the oil market.

It is expected that the next Article IV consultation with Kuwait will be held on the standard 12-month cycle.

Public Information Notices (PINs) form part of the IMF's efforts to promote transparency of the IMF's views and analysis of economic developments and policies. With the consent of the country (or countries) concerned, PINs are issued after Executive Board discussions of Article IV consultations with member countries, of its surveillance of developments at the regional level, of post-program monitoring, and of ex post assessments of member countries with longer-term program engagements. PINs are also issued after Executive Board discussions of general policy matters, unless otherwise decided by the Executive Board in a particular case. 
Kuwait: Selected Economic Indicators

\begin{tabular}{|c|c|c|c|c|c|}
\hline & 1999 & 2000 & 2001 & 2002 & 2003 \\
\hline & \multicolumn{5}{|c|}{ (Percent change) } \\
\hline \multicolumn{6}{|l|}{ Production and prices } \\
\hline Real GDP & -1.8 & 1.9 & 0.7 & -0.5 & 9.7 \\
\hline Real oil GDP & -6.5 & 2.2 & -3.3 & -7.9 & 19.8 \\
\hline Real non-oil GDP & 2.1 & 1.9 & 3.6 & 4.3 & 4.8 \\
\hline \multirow[t]{2}{*}{ Consumer price index } & 3.1 & 1.6 & 1.4 & 0.8 & 1.0 \\
\hline & \multicolumn{5}{|c|}{ (In percent of GDP; unless otherwise indicated) } \\
\hline \multicolumn{6}{|l|}{ Financial variables $1 /$} \\
\hline Total revenue, of which: & 68.9 & 80.2 & 63.1 & 65.2 & 60.6 \\
\hline Oil and gas $2 /$ & 46.8 & 55.5 & 43.1 & 49.4 & 46.8 \\
\hline Investment income 2/ & 19.3 & 20.3 & 13.2 & 10.5 & 8.8 \\
\hline Total expenditure & 39.9 & 39.4 & 45.6 & 43.9 & 41.5 \\
\hline Current & 36.4 & 36.2 & 40.8 & 38.8 & 36.3 \\
\hline Capital & 3.5 & 3.2 & 4.0 & 4.7 & 4.8 \\
\hline Overall fiscal balance & 29.0 & 40.8 & 17.5 & 21.3 & 19.1 \\
\hline Change in broad money supply (in percent) & 1.6 & 6.3 & 12.8 & 4.8 & 7.8 \\
\hline Interest rate (in percent) $3 /$ & 5.3 & 5.4 & 3.7 & 2.2 & 1.5 \\
\hline & \multicolumn{5}{|c|}{ (In millions of U.S. dollars; unless otherwise indicated) } \\
\hline \multicolumn{6}{|l|}{ External sector } \\
\hline Exports, f.o.b. of which: & 12,225 & 21,298 & 17,910 & 17,012 & 22,611 \\
\hline Crude oil and refined products & 11,029 & 18,182 & 14,977 & 14,057 & 19,004 \\
\hline Imports, c.i.f. & $-11,880$ & $-11,369$ & $-12,406$ & $-13,959$ & $-16,239$ \\
\hline Current account balance (deficit $=-$ ) & 5,010 & 14,671 & 8,328 & 4,250 & 7,318 \\
\hline In percent of GDP & 16.6 & 39.8 & 24.5 & 12.1 & 17.5 \\
\hline Central Bank of Kuwait's international reserves & 4,928 & 7,186 & 10,000 & 9,314 & 7,685 \\
\hline In months of imports of goods and services & 5.0 & 7.6 & 9.7 & 8.0 & 5.7 \\
\hline Real effective exchange rate (percent change) & 0.9 & 4.2 & 5.1 & -0.9 & -7.7 \\
\hline
\end{tabular}

Sources: Data provided by the authorities; and IMF Staff estimates.

1 / The fiscal year was changed from July-June to April-March effective 2001/02.

2/ Includes profits of public enterprises.

3/ Three-month Kuwaiti dinar deposits. 